\title{
Reactions of an Osmium(IV)-Hydroxo Complex with Amino-Boranes: Formation of Boroxide Derivatives
}

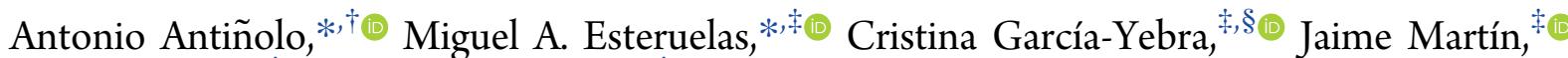 \\ Enrique Oñate, ${ }^{\ddagger}$ and Alberto Ramos ${ }^{\dagger}$
}

\begin{abstract}
†Departamento de Química Inorgánica, Orgánica y Bioquímica-Centro de Innovación en Química Avanzada (ORFEO-CINQA), Universidad de Castilla-La Mancha, Campus Universitario, E-13071 Ciudad Real, Spain

‡Departamento de Química Inorgánica, Instituto de Síntesis Química y Catálisis Homogénea (ISQCH), Centro de Innovación en Química Avanzada (ORFEO-CINQA), Universidad de Zaragoza-CSIC, 50009 Zaragoza, Spain
\end{abstract}

Supporting Information

\begin{abstract}
The discovery of a reaction which allows preparation of boroxide complexes of platinum group metals and study of their behavior under $\mathrm{CO}$ atmosphere is described. The trihydride-osmium(IV)-hydroxo complex $\mathrm{OsH}_{3}(\mathrm{OH})\left\{\kappa^{3}\right.$ $\left.P, O, P-\left[\operatorname{xant}\left(\mathrm{P}^{i} \mathrm{Pr}_{2}\right)_{2}\right]\right\} \quad\left(1, \operatorname{xant}\left(\mathrm{P}^{i} \mathrm{Pr}_{2}\right)_{2}=4,5-\mathrm{bis}-\right.$ (diisopropylphosphino)xanthene) reacts with the amino-boranes ${ }^{i} \operatorname{Pr}(\mathrm{H}) \mathrm{NBCy}_{2}$ and ${ }^{i} \operatorname{Pr}(\mathrm{H}) \mathrm{NBBN}$ to give the osmium(IV)boroxide derivatives $\mathrm{OsH}_{3}\left(\mathrm{OBR}_{2}\right)\left\{\kappa^{3}-P, O, P-\left[\operatorname{xant}\left(\mathrm{P}^{i} \mathrm{Pr}_{2}\right)_{2}\right]\right\}$ $\left(\mathrm{BR}_{2}=\mathrm{BCy}_{2}(2), \mathrm{BBN}(3) ; \mathrm{BBN}=9\right.$-borabicyclo[3.5.1]nonane) and ${ }^{i} \mathrm{PrNH}_{2}$ as a consequence of the addition of the $\mathrm{O}-\mathrm{H}$ bond of the hydroxo ligand of 1 to the $\mathrm{B}-\mathrm{N}$ bond of the amino-boranes. At room temperature under $\mathrm{CO}$ atmosphere, complexes 2 and 3 eliminate $\mathrm{H}_{2}$ to afford the osmium(II)boroxide compounds $\mathrm{OsH}\left(\mathrm{OBR}_{2}\right)(\mathrm{CO})_{2}\left\{\kappa^{2}-P, P-\left[\operatorname{xant}\left(\mathrm{P}^{i} \mathrm{Pr}_{2}\right)_{2}\right]\right\}\left(\mathrm{BR}_{2}=\mathrm{BCy}_{2}(4), \mathrm{BBN}(5)\right)$ bearing a $\kappa^{2}-P, P$-coordinated ether-diphosphine. The subsequent reductive elimination of the borinic acids $\mathrm{R}_{2} \mathrm{BOH}$ needs heating and a long duration and leads to the tricarbonyl-osmium(0) derivative $\mathrm{Os}(\mathrm{CO})_{3}\left\{\kappa^{2}-P, P-\left[\operatorname{xant}\left(\mathrm{P}^{i} \mathrm{Pr}_{2}\right)_{2}\right]\right\}$ (6) with the phosphorus atoms of the diphosphine lying in the equatorial plane of a pentagonal bypyramid of donor atoms around the metal center. In contrast to 2 and 3, under $\mathrm{CO}$ atmosphere, precursor 1 eliminates water to initially give the trans-dihydride $\mathrm{OsH}_{2}(\mathrm{CO})\left\{\kappa^{3}-P, O, P\right.$ $\left.\left[\mathrm{xant}\left(\mathrm{P}^{i} \mathrm{Pr}_{2}\right)_{2}\right]\right\}(7)$, which subsequently evolves to the cis-dihydride-cis-dicarbonyl derivative $\mathrm{OsH}_{2}(\mathrm{CO})_{2}\left\{\kappa^{2}-P, P\right.$ - $[\mathrm{xant}-$ $\left.\left.\left(\mathrm{P}^{i} \mathrm{Pr}_{2}\right)_{2}\right]\right\}(8)$ and finally into the tricarbonyl 6.
\end{abstract}

\section{INTRODUCTION}

Hydroxide complexes of platinum group metals ${ }^{1}$ are a rare and particularly fascinating group of weak hydroxoacids, which have an oxo derivative as a conjugate base, and are at the same time the strong conjugate base of an aquo-complex (Scheme 1 ). The exciting nature of these species does not correspond to

Scheme 1. Brønsted-Lowry Equilibria for a Metal Hydroxoacid

$$
\left[\mathrm{L}_{n} \mathrm{M}(\mathrm{OH})\right]^{\mathrm{n}} \stackrel{-\mathrm{H}^{+}}{=}\left[\mathrm{L}_{n} \mathrm{M}(\mathrm{OH})\right]^{\mathrm{n}-1} \stackrel{-\mathrm{H}^{+}}{=}\left[\mathrm{L}_{n} \mathrm{M}(\mathrm{O})\right]^{\mathrm{n}-\bar{\varepsilon}}
$$

a rich chemistry, which is by contrast underdeveloped, in particular for osmium. In addition to a few dimers, ${ }^{2}$ the mononuclear compounds of this element include nitride complexes, ${ }^{3}$ half-sandwich species, ${ }^{4}$ and hydride-hydroxo derivatives. ${ }^{5}$ The latter are particularly challenging because the reductive elimination of water is generally favored from a thermodynamic point of view. ${ }^{6}$ Compounds of this class are generally osmium(II)-derivatives and only very recently was isolated a hydride-osmium(IV)-hydroxo complex. ${ }^{5 f}$ In agreement with the marked ability of pincer ligands to stabilize uncommon species, ${ }^{7}$ it contains the POP group 4,5-bis(diisopropylphosphino)xanthene $\left(\operatorname{xant}\left(\mathrm{P}^{i} \mathrm{Pr}_{2}\right)_{2}\right){ }^{8}$

The previously mentioned duality of the hydroxide complexes is expressed in the respective nucleophilicity and electrophilicity of the oxygen and hydrogen atoms of the hydroxo group in the scarcely performed reactions, ${ }^{9}$ as the addition of aldehydes to $\left[\mathrm{OsH}(\mathrm{OH})(\mathrm{CPh})(\mathrm{IPr})\left(\mathrm{P}^{i} \mathrm{Pr}_{3}\right)\right] \mathrm{OTf}$ ( $\mathrm{IPr}=1,3$-bis(2,6-diisopropylphenyl)imidazolylidene, OTf = $\mathrm{CF}_{3} \mathrm{SO}_{3}$ ) which affords the corresponding carboxylate derivatives and molecular hydrogen (Scheme 2). ${ }^{10}$

Scheme 2. Reactions of an Osmium-Hydroxo Complex with Aldehydes

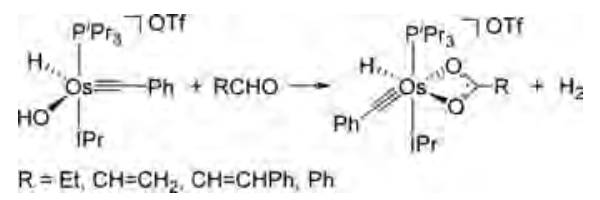

Received: October 8, 2018 
Boroxide groups have been proposed as promising alternative to the alkoxide ligands to better modulate the electronic and steric properties of catalyst precursors of interesting reactions of organic synthesis. ${ }^{11}$ The empty porbital on the boron allows electron donation from the oxygen lone-lone pairs, which gives rise to a poorer electron donating oxygen group. In addition, although the boroxide ligand bears twice as many carbon substituents as an alkoxide group, the presence of an additional space converts it to be sterically less demanding. ${ }^{12}$ Boroxide compounds of metal of $s$ and $p$ blocks ${ }^{13}$ and complexes of transition elements of all groups ${ }^{11,14}$ have been reported. Nevertheless, one could think that there is a "boroxide wall" around the platinum group metals because the species of these elements are unknown until now. Two main procedures have been employed to generate this type of compound: reactions of a metal halide with a lithium boroxide and protonolysis of metal-carbon, - nitrogen, or -oxygen bonds with a borinic acid ${ }^{12}$ ( $\mathrm{a}$ and $\mathrm{b}$ in Scheme 3 ).

\section{Scheme 3. Synthetic Procedures to Prepare Boroxide} Compounds

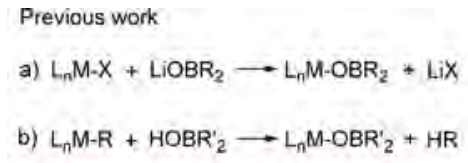

Boron shows higher affinity for oxygen than for nitrogen, which is consistent with the higher dissociation energy of the $\mathrm{B}-\mathrm{O}$ bonds with regard to the $\mathrm{B}-\mathrm{N}$ bonds in tricoordinate boron species. ${ }^{15}$ This, along with the oxygen nucleophilicity and the hydrogen electrophilicity of the hydroxo ligand in hydroxide complexes, prompted us to try the formation of boroxide species of a platinum group metal by means of the displacement of the amino group of amino-boranes by the conjugate base of a hydroxoacid (c in Scheme 3), in reactions that resemble that shown in Scheme 2. Here, we report a novel procedure which allowed us to isolate the first boroxide complexes of a platinum group metal.

\section{RESULTS AND DISCUSSION}

Osmium(IV)-Boroxide Derivatives: Formation and Characterization. Metal ions in high oxidation state form strong bonds with oxygen, increasing the electrophilicity of the hydrogen atom of the hydroxo ligand. This fact led us to select the osmium(IV) complex $\mathrm{OsH}_{3}(\mathrm{OH})\left\{\kappa^{3}-P, O, P\right.$-[xant$\left.\left.\left(\mathrm{P}^{i} \mathrm{Pr}_{2}\right)_{2}\right]\right\}(\mathbf{1})$ as starting point to achieve our goal. Treatment of toluene solutions of 1 with 1.0 equiv of the amino-boranes ${ }^{i} \operatorname{Pr}(\mathrm{H}) \mathrm{NBCy}_{2}$ and ${ }^{i} \operatorname{Pr}(\mathrm{H}) \mathrm{NBBN}$ (BBN = 9-borabicyclo[3.3.1]nonane) at room temperature for $30 \mathrm{~min}$ produces the release of isopropylamine and the formation of the desired osmium(IV)-boroxide derivatives $\mathrm{OsH}_{3}\left(\mathrm{OBR}_{2}\right)\left\{\kappa^{3}-P, O, P\right.$ - [xant$\left.\left.\left(\mathrm{P}^{i} \mathrm{Pr}_{2}\right)_{2}\right]\right\}\left(\mathrm{BR}_{2}=\mathrm{BCy}_{2}(2), \mathrm{BBN}(3)\right)$, which were isolated as pale yellow solids in $50-65 \%$ yield (Scheme 4 ).

The formation of $\mathbf{2}$ and $\mathbf{3}$ is strongly supported by the X-ray diffraction structure of 2 (Figure 1a). The Os(POP) skeleton shows the typical $\mathrm{T}$-shape with the osmium atom situated in the common vertex and $\mathrm{P} 1-\mathrm{Os}-\mathrm{P} 2, \mathrm{P} 1-\mathrm{Os}-\mathrm{O} 2$, and $\mathrm{P} 2-$ Os-O2 angles of $160.90(4)^{\circ}, 81.75(7)^{\circ}$, and $80.53(7)^{\circ}$,
Scheme 4. Formation of Boroxide Complexes 2 and 3

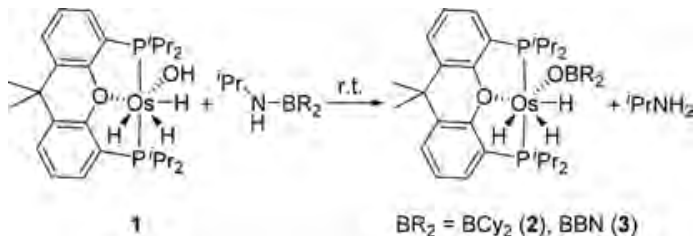

respectively. The coordination geometry around the metal center can be rationalized as a distorted pentagonal bipyramid with the boroxide group and the hydride ligands lying in the perpendicular plane to the $\mathrm{P}-\mathrm{Os}-\mathrm{P}$ direction along with the oxygen atom of the diphosphine, which is situated between the boroxide $\mathrm{O} 1$ atom and the hydride $\mathrm{H} 01$ (O1-Os-O2 = $\left.81.89(10)^{\circ}\right)$. The osmium-boroxide distance of 2.089(3) $\AA$ is long. It compares well with the higher part of the range of the reported osmium(IV)-alkoxide bond lengths (1.90-2.10 $\AA),{ }^{16}$ whereas the Os-O1-B1 angle of $137.9(3)^{\circ}$ significantly deviates from the expected value for $\mathrm{sp}^{2}$ hybridized oxygen. This angle is about $20^{\circ}$ larger than the Os-S-B angle in the borothiolate compounds $\mathrm{OsH}\left(\mathrm{SBR}_{2}\right)\left(\eta^{2}-\mathrm{H}_{2}\right)(\mathrm{CO})\left(\mathrm{P}^{i} \mathrm{Pr}_{3}\right)_{2}$ $\left(113-119^{\circ}\right){ }^{17}$ This is consistent with that observed by Braunschweig and co-workers for the $\mathrm{M}$-chalcogene-B angle, in the borachalcogene complexes $\mathrm{Cp}(\mathrm{CO})_{2} \mathrm{Mn}\left[\mathrm{EB}^{t} \mathrm{Bu}-\right.$ $(\mathrm{IMe})](\mathrm{E}=\mathrm{S}, \mathrm{Se}, \mathrm{Te})$, which increases by going up in the group, i.e., in the sequence $\mathrm{Te}<\mathrm{Se}<\mathrm{S}$. ${ }^{18}$ However, in contrast to the Braunschweig's compounds, the $\mathrm{O} 1-\mathrm{B}$ bond length of 1.332(6) A reveals a short chalcogene-boron single bond. ${ }^{19}$ The DFT optimized structure (Figure 1b) confirms the trihydride character of the $\mathrm{OsH}_{3}$ unit, although the calculated separations between $\mathrm{HO} 1$ and $\mathrm{HO2}$ and between $\mathrm{H} 02$ and $\mathrm{H} 03$ of 1.57 and $1.64 \AA$, respectively, suggest the presence of weak nonclassical interactions between the hydride ligands. ${ }^{20}$

The ${ }^{1} \mathrm{H}$ NMR spectra of $\mathbf{2}$ and 3 in toluene- $d_{8}$ also support the presence of weak nonclassical interactions between the hydride ligands. At room temperature, they display only one resonance $\left(\delta_{1 \mathrm{H}} \approx-13\right)$, indicating that they are involved in two thermally activated site exchange processes. At temperatures lower than $223 \mathrm{~K}$, three signals are however observed $\left(\delta_{1 \mathrm{H}}-11.60,-11.71,-13.49(2) ;-11.63,-11.75,-13.61\right.$ (3)) in agreement with the structures shown in Figure 1. Two of them form an $\mathrm{AB}$ spin system with a large cis $J_{\mathrm{AB}}$ coupling constant of $46.9 \mathrm{~Hz}$ for 2 and $98.5 \mathrm{~Hz}$ for 3 at $193 \mathrm{~K}$, which slightly decreases as the temperature increases, as expected for quantum-mechanical exchange coupling between the involved hydrides. ${ }^{21}$ According to equivalent $\mathrm{P}^{i} \mathrm{Pr}_{2}$ groups, the ${ }^{31} \mathrm{P}\left\{{ }^{1} \mathrm{H}\right\}$ NMR spectra contain a singlet at $44.2 \mathrm{ppm}$ for 2 and $45.6 \mathrm{ppm}$ for 3 , which is temperature invariant. In the ${ }^{11} \mathrm{~B}$ spectra, the boroxide ligands give rise to a broad resonance centered at $48.3 \mathrm{ppm}$ for 2 and at $50.6 \mathrm{ppm}$ for 3 .

Osmium(II)-Boroxide Derivatives: Reactions with CO. Complexes 2 and 3 are not only novel examples of boroxide derivatives but also notable polyhydrides bearing a monodentate monoanionic oxygen-donor ligand. ${ }^{20}$ The stability of the $\mathrm{H}-\mathrm{Os}-\mathrm{OBR}_{2}$ unit is certainly noticeable. In this context, it should be pointed out that the reductive elimination of molecular hydrogen is kinetically favored with regard to the release of the borinic acid. Thus, the stirring of toluene solutions of both compounds under $1 \mathrm{~atm}$ of CO at room temperature for $24 \mathrm{~h}$ leads to the respective cisdicarbonyl-hydride-osmium(II)-boroxide derivatives $\mathrm{OsH}$ $\left(\mathrm{OBR}_{2}\right)(\mathrm{CO})_{2}\left\{\kappa^{2}-P, P-\left[\operatorname{xant}\left(\mathrm{P}^{i} \mathrm{Pr}_{2}\right)_{2}\right]\right\}\left(\mathrm{BR}_{2}=\mathrm{BCy}_{2}(4), \mathrm{BBN}\right.$ 

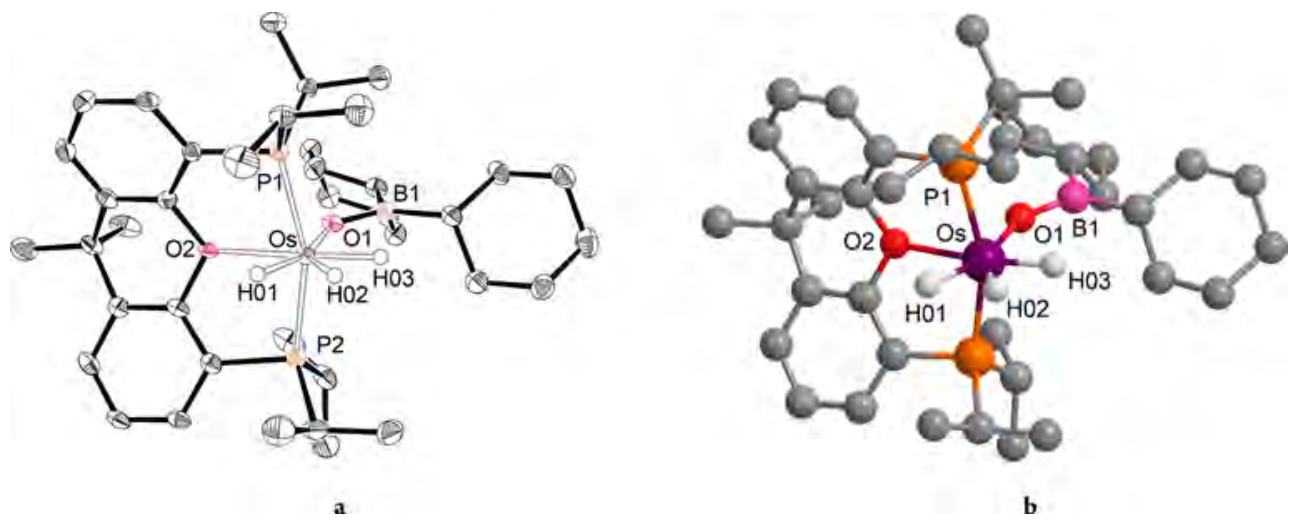

Figure 1. (a) Molecular diagram of complex 2 with 50\% probability ellipsoids. Hydrogen atoms (except hydrides) are omitted for clarity. Selected bond lengths $(\AA)$ and angles $(\mathrm{deg})$ : Os-O2 = 2.304(3), Os-O $1=2.089(3), \mathrm{Os}-\mathrm{H} 03=1.580(10), \mathrm{Os}-\mathrm{H} 02=1.580(10), \mathrm{Os}-\mathrm{H} 01=1.580(10)$, $\mathrm{Os}-\mathrm{P} 1=2.2893(11), \mathrm{Os}-\mathrm{P} 2=2.2891(11), \mathrm{O} 1-\mathrm{B} 1=1.332(6) ; \mathrm{P} 1-\mathrm{O} s-\mathrm{P} 2=160.90(4), \mathrm{P} 1-\mathrm{O} s-\mathrm{O} 2=81.75(7), \mathrm{P} 2-\mathrm{Os}-\mathrm{O} 2=80.53(7), \mathrm{O} 1-$ $\mathrm{Os}-\mathrm{O} 2=81.89(10), \mathrm{Os}-\mathrm{O} 1-\mathrm{B} 1=137.9(3)$. (b) DFT optimized structure of 2. Selected bond lengths $(\AA)$ and angles $(\mathrm{deg}): \mathrm{Os}-\mathrm{O} 2=2.351$, $\mathrm{Os}-\mathrm{O} 1=2.088$, Os-H03 = 1.594, Os-H02 = 1.598, Os-H01 = 1.633, Os-P1 = 2.322, Os-P2 = 2.321, O1-B1= 1.330, H01-H02 = 1.57, $\mathrm{H} 02-\mathrm{H} 03=1.64 ; \mathrm{P} 1-\mathrm{Os}-\mathrm{P} 2=160.5, \mathrm{P} 1-\mathrm{Os}-\mathrm{O} 2=81.5, \mathrm{P} 2-\mathrm{Os}-\mathrm{O} 2=80.3, \mathrm{O} 1-\mathrm{Os}-\mathrm{O} 2=78.1, \mathrm{Os}-\mathrm{O} 1-\mathrm{B} 1=140.7$.

(5)), and molecular hydrogen (Scheme 5). The elimination of the borinic acid takes place after the elimination of $\mathrm{H}_{2}$ on the

Scheme 5. Carbonylation of Complexes 2 and 3 in Toluene

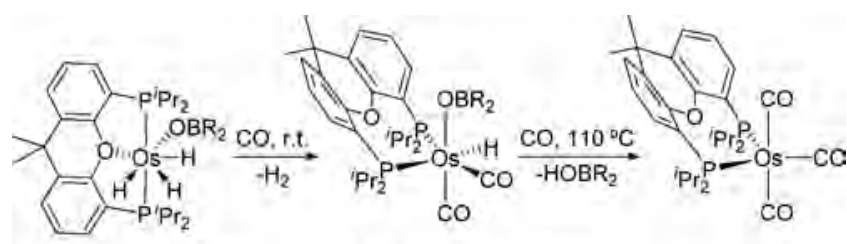

$\mathrm{BR}_{2}=\mathrm{BCy}_{2}(2), \mathrm{BBN}(3)$

$\mathrm{BR}_{2}=\mathrm{BCy}_{2}(4), \mathrm{BBN}(\mathbf{5})$

6

hydride-osmium(II)-boroxide species and requires heating and time. In toluene under 1 atm of $\mathrm{CO}$, complex 4 loses $\mathrm{HOBCy}_{2}$ to quantitatively afford the tricarbonyl compound $\mathrm{Os}(\mathrm{CO})_{3}\left\{\kappa^{2}-P, P-\left[\operatorname{xant}\left(\mathrm{P}^{i} \mathrm{Pr}_{2}\right)_{2}\right]\right\}(6)$ after 4 days at $110{ }^{\circ} \mathrm{C}$. The $\mathrm{C}$-substituents attached to the boron atom influence the elimination rate of the borinic acid. The bicyclic system of $\mathbf{5}$ favors the reductive elimination with regard to the cyclohexyl groups of $\mathbf{4}$. As a consequence, complex $\mathbf{5}$ cannot be isolated as an analytically pure solid because amounts of the tricarbonyl derivative $\mathbf{6}$ are formed before the quantitative transformation of $\mathbf{3}$ into $\mathbf{5}$ has taken place, even at room temperature.

Complex 4 was isolated as a white solid in $64 \%$ yield and characterized by X-ray diffraction analysis. The structure (Figure 2) proves the reduction of the metal center from +4 to +2 , involving the replacement of two hydride ligands by two carbonyl groups. The reduction produces a change in the coordination mode of the diphosphine from $\kappa^{3}-P, O, P$ to $\kappa^{2}-P, P$, in agreement with the flexibility of the ether-diphosphines, which allows them to adapt to the requirements of the particular complex. ${ }^{8 c, i, j, 22}$ The formation of $\mathbf{4}$ and $\mathbf{5}$ enlarges into osmium(II), the range of osmium(VI) and osmium(IV) species stabilized by $\kappa^{2}-P, P$-coordinated ether-diphosphines. The coordination polyhedron around the osmium atom can be rationalized as a distorted octahedron with the boroxide ligand disposed trans to a carbonyl group $\mathrm{O} 1-\mathrm{Os}-\mathrm{C} 1=174.90(8)^{\circ}$. The perpendicular plane is formed by the other carbonyl group, the hydride ligand, and the phosphorus atoms of the chelate diphosphine $\left(\mathrm{P} 1-\mathrm{Os}-\mathrm{P} 2=108.33(2)^{\circ}\right)$. The coordination of the boroxide ligand does not show any

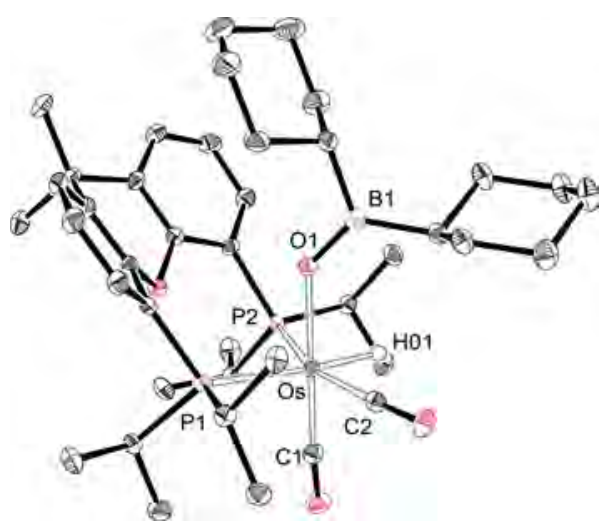

Figure 2. Molecular diagram of complex 4 with 50\% probability ellipsoids. Hydrogen atoms (except the hydride) are omitted for clarity. Selected bond lengths $(\AA)$ and angles (deg): Os-O1 = $2.0857(15), \mathrm{Os}-\mathrm{H} 01=1.584(10), \mathrm{Os}-\mathrm{C} 2=1.886(2), \mathrm{Os}-\mathrm{C} 1=$ $1.865(2), \mathrm{Os}-\mathrm{P} 1=2.5092(6), \mathrm{Os}-\mathrm{P} 2=2.4522(6), \mathrm{O} 1-\mathrm{B}=$ $1.331(3)$; O $1-\mathrm{Os}-\mathrm{C} 1=174.90(8), \mathrm{P} 1-\mathrm{Os}-\mathrm{P} 2=108.33(2)$, Os$\mathrm{O} 1-\mathrm{B}=135.33(16)$

difference with regard to the coordination in 2 . Thus, the Os$\mathrm{O} 1$ and $\mathrm{O} 1-\mathrm{B}$ bond lengths of 2.0857(15) and 1.331(3) A, respectively, and the $\mathrm{Os}-\mathrm{O} 1-\mathrm{B}$ angle of $135.33(16)^{\circ}$ are almost identical as those of 2 .

The IR and ${ }^{13} \mathrm{C}\left\{{ }^{1} \mathrm{H}\right\},{ }^{1} \mathrm{H}$, and ${ }^{31} \mathrm{P}\left\{{ }^{1} \mathrm{H}\right\}$ NMR spectra of 4 in toluene- $d_{8}$ at $203 \mathrm{~K}$ are consistent with the structure shown in Figure 2. As expected for a cis disposition of the carbonyl groups, the IR contains the characteristic two $\nu(\mathrm{CO})$ bands corresponding to a $\mathrm{C}_{2 \mathrm{v}}$ point group at 1998 and $1914 \mathrm{~cm}^{-1}$. In the ${ }^{13} \mathrm{C}\left\{{ }^{1} \mathrm{H}\right\}$ NMR spectrum, these ligands display double doublets at $186.0\left({ }^{2} J_{\mathrm{C}-\mathrm{P} \text { trans }}=99.8 \mathrm{~Hz},{ }^{2} \mathrm{~J}_{\mathrm{C}-\mathrm{P} \text { cis }}=1.0 \mathrm{~Hz}\right)$ and $181.8\left({ }^{2} J_{\mathrm{C}-\mathrm{P} \text { cis }}=10.5\right.$ and $\left.2.1 \mathrm{~Hz}\right) \mathrm{ppm}$. In agreement with the presence of a hydride ligand disposed trans to a phosphorus atom and cis to other one, the high field region of the ${ }^{1} \mathrm{H}$ NMR spectrum shows at $-6.30 \mathrm{ppm}$ a double doublet with $\mathrm{H}-\mathrm{P}$ coupling constants of 115.1 and $33.6 \mathrm{~Hz}$, whereas the ${ }^{31} \mathrm{P}\left\{{ }^{1} \mathrm{H}\right\}$ NMR spectrum contains two doublets at 3.4 and $1.5 \mathrm{ppm}$ with a P-P coupling constant of $26.2 \mathrm{~Hz}$. In accordance with 2 , the ${ }^{11} \mathrm{~B}$ NMR spectrum in toluene- $d_{8}$ at room temperature shows a broad resonance centered at $50.0 \mathrm{ppm}$. 
Complex 5 exists in solution as a 1:1 mixture of two conformers, which may be related to the disposition of the xanthene linker of the diphosphine with regard to the ligands situated along the boroxide-osmium-carbonyl axis. Their presence is strongly supported by the ${ }^{1} \mathrm{H}$ and ${ }^{31} \mathrm{P}\left\{{ }^{1} \mathrm{H}\right\}$ NMR spectra in toluene- $d_{8}$ at $203 \mathrm{~K}$. Thus, in agreement with the ${ }^{1} \mathrm{H}$ NMR spectrum of 4 , the ${ }^{1} \mathrm{H}$ NMR spectrum of 5 shows two double doublets at $-5.94\left({ }^{2} J_{\mathrm{P}-\mathrm{H} \text { trans }}=99.0 \mathrm{~Hz},{ }^{2} J_{\mathrm{P}-\mathrm{H} \text { cis }}=\right.$ $29.94 \mathrm{~Hz})$ and $-6.31\left({ }^{2} J_{\mathrm{P}-\mathrm{H} \text { trans }}=107.5 \mathrm{~Hz},{ }^{2} J_{\mathrm{P}-\mathrm{H} \text { cis }}=32.5\right.$ $\mathrm{Hz})$ ppm, corresponding to the hydride ligand of each conformer, whereas the ${ }^{31} \mathrm{P}\left\{{ }^{1} \mathrm{H}\right\}$ NMR spectrum contains four doublets at 20.7 and $11.4\left({ }^{2} J_{\mathrm{P}-\mathrm{P}}=24.5 \mathrm{~Hz}\right) \mathrm{ppm}$ and 13.1 and $12.0\left({ }^{2} J_{\mathrm{P}-\mathrm{P}}=24.5 \mathrm{~Hz}\right) \mathrm{ppm}$, two for each conformer.

The osmium(0)-tricarbonyl complex 6 was isolated as a yellow solid in $41 \%$ yield and characterized by X-ray diffraction analysis. Figure 3 shows a view of the molecule. The

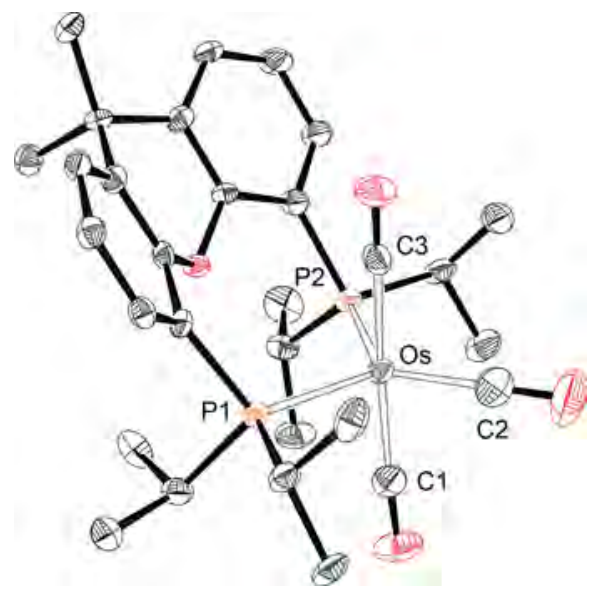

Figure 3. Molecular diagram of complex 6 with 50\% probability ellipsoids. Hydrogen atoms are omitted for clarity. Selected bond lengths $(\AA)$ and angles (deg): Os-C3 = 1.931(5), Os-C2 = $1.856(5), \mathrm{Os}-\mathrm{C} 1=1.928(5), \mathrm{Os}-\mathrm{P} 1=2.3582(11), \mathrm{Os}-\mathrm{P} 2=$ 2.3677(11); $\mathrm{C} 1-\mathrm{Os}-\mathrm{C} 3=175.12(19), \mathrm{P} 1-\mathrm{Os}-\mathrm{P} 2=114.10(4)$, $\mathrm{P} 2-\mathrm{Os}-\mathrm{C} 2=123.63(17), \mathrm{P} 1-\mathrm{Os}-\mathrm{C} 2=122.09(17)$.

coordination polyhedron around the osmium atom can be rationalized as a distorted trigonal bipyramid with two carbonyl groups at the apexes $\left(\mathrm{C} 1-\mathrm{Os}-\mathrm{C} 3=175.12(19)^{\circ}\right)$. The phosphorus atoms of the $\kappa^{2}$-coordinated ether-diphosphine and the remaining carbonyl group lie in the equatorial plane, forming $\mathrm{P} 1-\mathrm{Os}-\mathrm{P} 2, \mathrm{P} 2-\mathrm{Os}-\mathrm{C} 2$, and $\mathrm{C} 2-\mathrm{Os}-\mathrm{P} 1$ angles of $114.10(4)^{\circ}, 123.63(17)^{\circ}$, and $122.09(17)^{\circ}$, respectively. The distances between the metal center and the apical carbonyl groups of 1.928(5) (Os-C1) and 1.931(5) (Os-C3) $\AA$ are about $0.08 \AA$ longer than the distance between the osmium atom and the equatorial carbonyl group of $1.856(5)$
(Os-C2) A. In agreement with the disposition of the carbonyl ligands, the IR in toluene contains three $\nu(\mathrm{CO})$ bands at 2003, 1916 , and $1900 \mathrm{~cm}^{-1}$ with weak, very strong, and strong intensities, respectively. The equivalent phosphorus atoms of the diphosphine display a singlet at $4.5 \mathrm{ppm}$ in the ${ }^{31} \mathrm{P}\left\{{ }^{1} \mathrm{H}\right\}$ NMR spectrum in dichloromethane at room temperature. Complex 6 is notable for two reasons: (i) it enlarges into osmium(0) the range of compounds involving a $\kappa^{2}-P, P$ coordinated ether-diphosphine and (ii) it is a rare example of $\mathrm{Os}(\mathrm{CO})_{3} \mathrm{P}_{2}$ compound with the phosphorus atoms lying in the equatorial plane of the bipyramid because they always occupy apical positions in the complexes of this class previously reported. $^{23}$

Reactions of 1 with CO: Reductive Elimination of $\mathrm{H}_{2} \mathrm{O}$. There are marked differences in behavior between the hydroxo precursor $\mathbf{1}$ and the boroxide derivatives 2 and 3 under 1 atm of $\mathrm{CO}$. In contrast to the latter, complex 1 eliminates the oxygen donor group and a hydride ligand to quantitatively yield the previously described trans-dihydride compound $\mathrm{OsH}_{2}(\mathrm{CO})\left\{\kappa^{3}-P, O, P-\left[\operatorname{xant}\left(\mathrm{P}^{i} \mathrm{Pr}_{2}\right)_{2}\right]\right\}^{8 \mathrm{~h}} \quad(7)$ and water after $24 \mathrm{~h}$ in toluene at room temperature (Scheme 6). At $110{ }^{\circ} \mathrm{C}$, complex 7 evolves into the cis-dicarbonyl derivative $\mathrm{OsH}_{2}(\mathrm{CO})_{2}\left\{\kappa^{2}-P, P\right.$ - $\left.\left[\operatorname{xant}\left(\mathrm{P}^{i} \mathrm{Pr}_{2}\right)_{2}\right]\right\}(\mathbf{8})$, as a result of the displacement of the oxygen atom of the diphosphine by a second carbon monoxide molecule and the trans to cis isomerization of the hydride ligands. Complex $\mathbf{8}$, which is a new example of osmium(II) species with a $\kappa^{2}-P, P$-coordinated ether-diphosphine, is a dihydride counterpart of $\mathbf{4}$ and 5 bearing a hydride ligand in the position of the boroxide group. Like its analogue, it undergoes reduction into the tricarbonyl derivative 6 under carbon monoxide atmosphere.

The $\kappa^{2}-P, P$-coordination of the diphosphine in $\mathbf{8}$ is strongly supported by the ${ }^{1} \mathrm{H}$ NMR spectrum of the complex in toluene- $d_{8}$ at room temperature, which shows two double doublets at 0.97 and $0.89 \mathrm{ppm}$ for the methyl groups of the phosphine isopropyl substituents instead of the characteristic doublet of virtual triplets of the $\kappa^{3}-P, O, P$-mer mode. In addition, in the high field region, the spectrum contains two doublet of doublet of doublets at -7.92 (hydride cis to both $\mathrm{P}$ atoms) and -10.01 (hydride trans to a $\mathrm{P}$ atom and cis to the other one) ppm with P-P coupling constants of 19.6 and 26.4 and 67.5 and $35.5 \mathrm{~Hz}$, respectively, and a $\mathrm{H}-\mathrm{H}$ coupling constant of $6.1 \mathrm{~Hz}$. The ${ }^{13} \mathrm{C}\left\{{ }^{1} \mathrm{H}\right\}$ NMR spectrum also supports the structure proposed for $\mathbf{8}$ in Scheme 6, showing the carbonyl resonances at 188.0 (CO trans to a $\mathrm{P}$ atom and cis to the other one) and 186.0 (CO cis to $\mathrm{P}$ atoms) ppm as double doublets with $\mathrm{C}-\mathrm{P}$ coupling constants of 74.1 and $3.4 \mathrm{~Hz}$ and 10.0 and $3.6 \mathrm{~Hz}$, respectively. In the ${ }^{31} \mathrm{P}\left\{{ }^{1} \mathrm{H}\right\}$ NMR spectrum, the inequivalent $\mathrm{P}^{i} \mathrm{Pr}_{2}$ groups display at 4.2 and $1.9 \mathrm{ppm}$ doublets with a $\mathrm{P}-\mathrm{P}$ coupling constant of $25.6 \mathrm{~Hz}$.

\section{Scheme 6. Carbonylation of Complex 1 in Toluene}

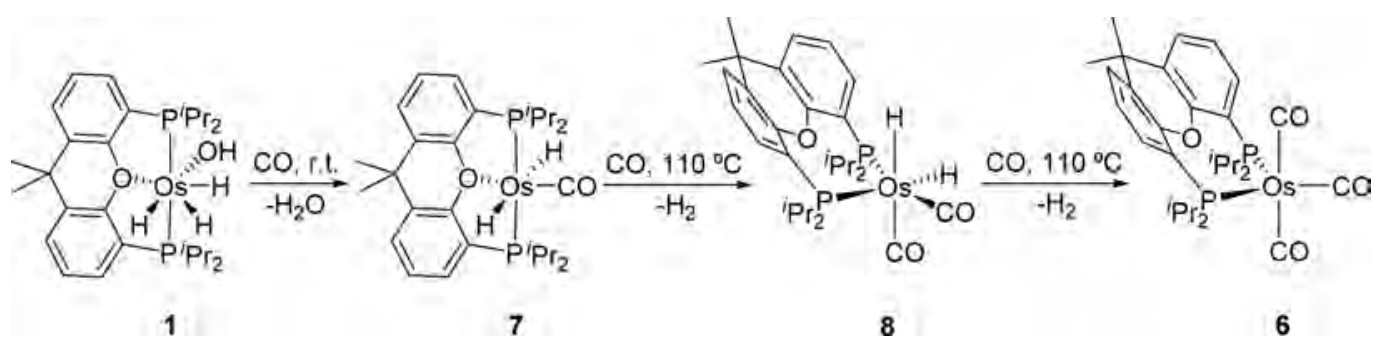




\section{CONCLUDING REMARKS}

This study shows a novel reaction in the chemistry of hydroxotransition-metal complexes, reveals the existence of boroxide derivatives of platinum group metals, demonstrates that the reductive elimination of borinic acids from hydride metalboroxide compounds is disfavored with regard to the release of molecular hydrogen and to the reductive elimination of water from hydride-metal-hydroxo counterparts, and enlarges the range of metal ions stabilizing compounds with $\kappa^{2}-P, P$ coordinated ether-diphosphines.

The oxygen nucleophilicity and hydrogen electrophilicity of hydroxo ligands coordinated to transition metals allow the hydroxo ligand to displace the amino group of $\mathrm{R}_{2} \mathrm{NBR}_{2}$ amino-boranes. The reactions afford boroxide derivatives, including compounds of a platinum group metal as osmium. Complexes of this class containing hydride coligands are stable toward the elimination of borinic acids, in contrast to hydridemetal-hydroxo species which show a high tendency to release water. Under carbon monoxide atmosphere, the elimination of molecular hydrogen is observed. The elimination of the borinic acid also occurs but is always a subsequent process and needs heating and a long duration. The ether-diphosphine 4,5bis(diisopropylphosphino)xanthene stabilizes the resulting species of the above-mentioned processes when the metal center is osmium, adapting its coordination mode to the electronic and steric requirements of each particular complex. As a consequence, the range of compounds bearing the diphosphine $\kappa^{2}-P, P$-coordination was enlarged into osmium(II) and osmium(0) derivatives.

In conclusion, a novel reaction in the chemistry of transitionmetal-hydroxo complexes has been discovered, which has led us to the preparation of the first boroxide derivatives of a platinum group metal and study of their behavior under a carbon monoxide atmosphere.

\section{EXPERIMENTAL SECTION}

All reactions were performed under argon using Schlenk tube or glovebox techniques and dried solvents. Instrumental methods, NMR spectra, X-ray diffraction analysis information and DFT computational details are given in the Supporting Information. Complex $\mathrm{OsH}_{3}(\mathrm{OH})$ $\left\{\kappa^{3}-P, O, P\right.$ - $\left.\left[\operatorname{xant}\left(\mathrm{P}^{i} \mathrm{Pr}_{2}\right)_{2}\right]\right\}(\mathbf{1})$ was prepared as published. ${ }^{5 \mathrm{f}}$ Chemical shifts (expressed in parts per million) are referenced to residual solvent peaks $\left({ }^{1} \mathrm{H},{ }^{13} \mathrm{C}\left\{{ }^{1} \mathrm{H}\right\}\right)$ or external $\mathrm{H}_{3} \mathrm{PO}_{4}\left({ }^{31} \mathrm{P}\left\{{ }^{1} \mathrm{H}\right\}\right)$ and $\mathrm{BF}_{3}$. $\mathrm{OEt}_{2}\left({ }^{11} \mathrm{~B}\right)$. Coupling constants $J$ and $N\left(N=J_{\mathrm{PH}}+J_{\mathrm{P}^{\prime} \mathrm{H}}\right.$ for ${ }^{1} \mathrm{H} ; N=$ $J_{\mathrm{PC}}+J_{\mathrm{P}^{\prime} \mathrm{C}}$ for ${ }^{13} \mathrm{C}$ ) are given in Hertz.

Preparation of ${ }^{i} \mathrm{PrNHBCy}_{2}$. A $1.6 \mathrm{M}$ solution of ${ }^{n} \mathrm{BuLi}$ in hexane $(3.2 \mathrm{~mL}, 5.12 \mathrm{mmol}$ ) was slowly added to a colorless solution of isopropylamine $(430 \mu \mathrm{L}, 5.00 \mathrm{mmol})$ in diethyl ether $(10 \mathrm{~mL})$ kept at $-78{ }^{\circ} \mathrm{C}$ with an acetone/liquid $\mathrm{N}_{2}$ bath. Upon finishing the addition, formation of a white precipitate $\left(\mathrm{LiNH}^{i} \mathrm{Pr}\right)$ was observed; then, the cold bath was removed, and the mixture was further stirred at room temperature for $1 \mathrm{~h}$. Then, the white suspension thus obtained was again cooled at $-78{ }^{\circ} \mathrm{C}$, and a $1.0 \mathrm{M}$ solution of $\mathrm{ClBCy}_{2}$ in hexane $(5.0 \mathrm{~mL}, 5.00 \mathrm{mmol})$ was slowly added. Once more, the bath was removed when the addition was finished, and the mixture was further stirred for $2 \mathrm{~h}$ at room temperature to ensure reaction completion, after which time was left standing for $1 \mathrm{~h}$ to allow deposition of solid $\mathrm{LiCl}$ at the bottom of the flask. Then, the solution was filtered with a cannula and a small amount of Celite, and the solvents were subsequently removed under vacuum to afford the amino-borane ${ }^{i} \mathrm{PrNHBCy}_{2}$ as a colorless viscous oil $(950 \mathrm{mg}, 81 \%) .{ }^{1} \mathrm{H}$ NMR (500 $\left.\mathrm{MHz}, \mathrm{C}_{6} \mathrm{D}_{6}, 298 \mathrm{~K}\right): \delta 3.61\left(\mathrm{~d}, \mathrm{br}, J_{\mathrm{HH}}=11.1,1 \mathrm{H}, \mathrm{NH}\right), 3.51$ (dsept, $\left.1 \mathrm{H}, J_{\mathrm{HH}}=11.1,6.3,1 \mathrm{H}, \mathrm{CH}-{ }^{i} \mathrm{Pr}\right), 1.9-0.9(\mathrm{~m}, 22 \mathrm{H}, \mathrm{Cy}), 0.93(\mathrm{~d}, J=$ 6.3, $\left.6 \mathrm{H}, \mathrm{CH}_{3}{ }^{i} \mathrm{Pr}\right) .{ }^{13} \mathrm{C}\left\{{ }^{1} \mathrm{H}\right\}$ NMR $\left(101 \mathrm{MHz}, \mathrm{C}_{6} \mathrm{D}_{6}, 298 \mathrm{~K}\right): \delta 43.2(\mathrm{~s}$ CH- $\left.{ }^{i} \mathrm{Pr}\right), 30.2,29.5$ (2s, $\left.2 \times \mathrm{C}^{2,3}-\mathrm{Cy}\right), 29.3\left(\mathrm{br}, \mathrm{C}^{1}-\mathrm{Cy}\right), 28.6(\mathrm{~s}, 2 \times$
$\left.\mathrm{C}^{2,3}-\mathrm{Cy}\right), 27.7,27.6\left(2 \mathrm{~s}, 2 \times \mathrm{C}^{4}-\mathrm{Cy}\right), 26.7\left(\mathrm{~s}, \mathrm{CH}_{3}{ }^{\mathrm{i}} \mathrm{Pr}\right) .{ }^{11} \mathrm{~B}$ NMR $\left(160 \mathrm{MHz}, \mathrm{C}_{6} \mathrm{D}_{6}\right) \delta 44.7$ (s, $\Delta \nu_{1 / 2}$ ca. $\left.260 \mathrm{~Hz}, \mathrm{~B}\right)$.

Preparation of ${ }^{i}$ PrNHBBN. A toluene solution $(15 \mathrm{~mL})$ containing $(\mathrm{H}-\mathrm{BBN})_{2}(610 \mathrm{mg}, 2.50 \mathrm{mmol})$ and excess isopropylamine $(470 \mu \mathrm{L}, 5.47 \mathrm{mmol})$ was stirred for $20 \mathrm{~h}$ at $60{ }^{\circ} \mathrm{C}$. Then, the solvent was removed under vacuum to yield the amino-borane ${ }^{i}$ PrNHBBN as a colorless viscous oil (640 mg, 71\%). ${ }^{1} \mathrm{H}$ NMR (400 $\mathrm{MHz}, \mathrm{C}_{6} \mathrm{D}_{6}, 298 \mathrm{~K}$ ): $\delta 3.54$ (br, $1 \mathrm{H}, \mathrm{NH}$ ), 3.39 (dsept, $J=10.1,6.4$, $\left.1 \mathrm{H}, \mathrm{CH}-{ }^{i} \mathrm{Pr}\right), 2.10-0.95(\mathrm{~m}, 14 \mathrm{H}, \mathrm{BBN}), 0.90(\mathrm{~d}, J=6.4,6 \mathrm{H}$, $\left.\mathrm{CH}_{3}{ }^{-} \mathrm{Pr}\right) .{ }^{13} \mathrm{C}\left\{{ }^{1} \mathrm{H}\right\}$ NMR $\left(101 \mathrm{MHz}, \mathrm{C}_{6} \mathrm{D}_{6}, 298 \mathrm{~K}\right): \delta 43.6(\mathrm{~s}$ $\left.\mathrm{CH}-{ }^{i} \mathrm{Pr}\right), 34.0,33.6\left(2 \mathrm{~s}, 2 \times \mathrm{CH}_{2}-\mathrm{BBN}\right), 27.1$ (br, $\left.\mathrm{CH}-\mathrm{BBN}\right), 26.6$ (s, $\mathrm{CH}_{3}-{ }^{i} \mathrm{Pr}$ ), 24.1 (s, $\left.\mathrm{CH}_{2}-\mathrm{BBN}\right), 22.3$ (br, $\left.\mathrm{CH}-\mathrm{BBN}\right) .{ }^{11} \mathrm{~B}$ NMR (128 $\left.\mathrm{MHz}, \mathrm{C}_{6} \mathrm{D}_{6}, 298 \mathrm{~K}\right): \delta 47.9\left(\mathrm{~s}, \Delta \nu_{1 / 2}\right.$ ca. $\left.120 \mathrm{~Hz}, \mathrm{~B}\right)$.

Reaction of 1 with 'PrNHBCy: Preparation of $\mathrm{OsH}_{3}\left(\mathrm{OBCy}_{2}\right)$ $\left\{\boldsymbol{\kappa}^{3}-P, O, P\right.$ - $\left.\left[x a n t\left(\mathrm{P}^{i} \mathrm{Pr}_{2}\right)_{2}\right]\right\}$ (2). Amino-borane ${ }^{i} \mathrm{PrNHBCy}_{2}$ (43 mg, $0.184 \mathrm{mmol})$ was added to a solution of $1(120 \mathrm{mg}, 0.184 \mathrm{mmol})$ in toluene $(5 \mathrm{~mL})$. After $30 \mathrm{~min}$ at room temperature, the solution was concentrated, and $2 \mathrm{~mL}$ of acetone was added at $-50{ }^{\circ} \mathrm{C}$ to afford a pale yellow solid, which was washed twice with acetone $(1 \mathrm{~mL})$ and dried under reduced pressure. Yield: $95 \mathrm{mg}(62 \%)$. Anal. Calcd for $\mathrm{C}_{39} \mathrm{H}_{65} \mathrm{BO}_{2} \mathrm{OsP}_{2}$ : C, 56.51; H, 7.90. Found: C, 56.92; H, 7.91. ${ }^{1} \mathrm{H}$ $\operatorname{NMR}\left(300.13 \mathrm{MHz}, \mathrm{C}_{4} \mathrm{D}_{8} \mathrm{O}, 298 \mathrm{~K}\right): \delta 7.60\left(\mathrm{dd},{ }^{3} J_{\mathrm{HH}}=7.7,{ }^{4} J_{\mathrm{HH}}=\right.$ 1.2, $2 \mathrm{H}, \mathrm{CH}$-arom POP), $7.50(\mathrm{~m}, 2 \mathrm{H}, \mathrm{CH}$-arom $\mathrm{POP}), 7.27$ (dd, ${ }^{3} J_{\mathrm{HH}}=7.6,{ }^{3} J_{\mathrm{HH}}=7.5,2 \mathrm{H}, \mathrm{CH}$-arom POP $), 2.51(\mathrm{~m}, 2 \mathrm{H}$, $\left.\mathrm{PCH}\left(\mathrm{CH}_{3}\right)_{2}\right), 2.26\left(\mathrm{~m}, 2 \mathrm{H}, \mathrm{PCH}\left(\mathrm{CH}_{3}\right)_{2}\right), 1.89$ (s, 3H, $\left.\mathrm{CH}_{3} \mathrm{POP}\right)$, 1.63-1.52 (10H, $\left.\mathrm{CH}_{2} \mathrm{Cy}\right), 1.48$ (s, $\left.3 \mathrm{H}, \mathrm{CH}_{3} \mathrm{POP}\right), 1.21-0.94(10 \mathrm{H}$, $\left.\mathrm{CH}_{2} \mathrm{Cy} ; 18 \mathrm{H}, \mathrm{PCH}\left(\mathrm{CH}_{3}\right)_{2}\right), 0.81(\mathrm{~m}, 2 \mathrm{H}, \mathrm{CH} \mathrm{Cy}), 0.73\left(\mathrm{dvt},{ }^{3} J_{\mathrm{HH}}=\right.$ 6.9, $\left.\mathrm{N}=14.2,6 \mathrm{H}, \mathrm{PCH}\left(\mathrm{CH}_{3}\right)_{2}\right),-12.72\left(\mathrm{t},{ }^{3} J_{\mathrm{HP}}=11.4,3 \mathrm{H}, \mathrm{OsH}\right)$. ${ }^{1} \mathrm{H}$ NMR $\left(400.13 \mathrm{MHz}, \mathrm{C}_{7} \mathrm{D}_{8}, 193 \mathrm{~K}\right): \delta v_{\mathrm{A}}=-11.60$ and $v_{\mathrm{B}}=$ -13.49 (AB system, $\left.{ }^{2} J_{\mathrm{AB}}=46.9,2 \mathrm{H}, \mathrm{Os} H\right),-11.71(\mathrm{br}, 1 \mathrm{H}, \mathrm{OsH})$. ${ }^{13} \mathrm{C}\left\{{ }^{1} \mathrm{H}\right\}$-APT NMR $\left(75.47 \mathrm{MHz}, \mathrm{C}_{4} \mathrm{D}_{8} \mathrm{O}, 298 \mathrm{~K}\right.$ ): $\delta 159.8$ (vt, $N=$ 13.3, $C$-arom POP), 133.5 (vt, $N=5.6, C$-arom POP), $131.0(\mathrm{~s}, \mathrm{CH}$ arom POP), 129.8 (vt, $N=27.9, C$-arom POP), 127.6 (s, $C H$-arom POP), 125.7 (s, CH-arom POP), 36.1 (br, $\mathrm{CH} \mathrm{Cy}), 35.5$ (s, $\mathrm{C}\left(\mathrm{CH}_{3}\right)_{2}$ POP), 34.5 (s, $\left.\mathrm{C}\left(\mathrm{CH}_{3}\right)_{2} \mathrm{POP}\right), 30.3$ and $29.4\left(\mathrm{~s}, \mathrm{CH}_{2} \mathrm{Cy}\right), 28.6$ (vt, $\left.N=19.2, \mathrm{PCH}\left(\mathrm{CH}_{3}\right)_{2}\right), 28.4$ (s, $\left.\mathrm{CH}_{2} \mathrm{Cy}\right), 26.7$ (vt, $\mathrm{N}=33.2$, $\left.\mathrm{PCH}\left(\mathrm{CH}_{3}\right)_{2}\right), 26.4\left(\mathrm{~s}, \mathrm{C}\left(\mathrm{CH}_{3}\right)_{2} \mathrm{POP}\right), 21.1$ (vt, $\mathrm{N}=10.8$, $\left.\mathrm{PCH}\left(\mathrm{CH}_{3}\right)_{2}\right), 20.8$ (s, $\left.\mathrm{PCH}\left(\mathrm{CH}_{3}\right)_{2}\right), 20.5$ (s, $\left.\mathrm{PCH}\left(\mathrm{CH}_{3}\right)_{2}\right), 20.0$ (vt, $\left.\mathrm{N}=4.5, \mathrm{PCH}\left(\mathrm{CH}_{3}\right)_{2}\right) \cdot{ }^{31} \mathrm{P}\left\{{ }^{1} \mathrm{H}\right\}$ NMR $\left(161.98 \mathrm{MHz}, \mathrm{C}_{7} \mathrm{D}_{8}, 298\right.$ $\mathrm{K}): 44.2$ (s, POP). ${ }^{11} \mathrm{~B}$ NMR $\left(96.30 \mathrm{MHz}, \mathrm{C}_{6} \mathrm{D}_{6}, 298 \mathrm{~K}\right): \delta 48.3$ (br). $T_{1}(\mathrm{~min})\left(\mathrm{ms}, \mathrm{OsH}, 400.13 \mathrm{MHz}, \mathrm{C}_{7} \mathrm{D}_{8}, 263 \mathrm{~K}\right): 74 \pm 4(-12.39$ $\mathrm{ppm}$ ). Crystals suitable for X-ray diffraction analysis were obtained by slow diffusion of pentane into a toluene solution of the complex at $-30{ }^{\circ} \mathrm{C}$.

Reaction of 1 with ${ }^{i} \mathrm{PrNHBBN}$ : Preparation of $\mathrm{OsH}_{3}(\mathrm{OBBN})$ $\left\{\boldsymbol{\kappa}^{3}-P, O, P\right.$ - $\left.\left[x a n t\left(\mathrm{P}^{i} \mathrm{Pr}_{2}\right)_{2}\right]\right\}$ (3). Amino-borane ${ }^{i} \mathrm{PrNHBBN}$ (35 mg, $0.195 \mathrm{mmol})$ was added to a solution of $1(120 \mathrm{mg}, 0.184 \mathrm{mmol})$ in toluene $(5 \mathrm{~mL})$. After $30 \mathrm{~min}$ at room temperature, the solution was concentrated, and $2 \mathrm{~mL}$ of acetone was added at $-50{ }^{\circ} \mathrm{C}$ to afford a pale yellow solid, which was washed twice with acetone $(1 \mathrm{~mL})$ and dried under reduced pressure. Yield: $73 \mathrm{mg}$ (51\%). Anal. Calcd for $\mathrm{C}_{35} \mathrm{H}_{57} \mathrm{BO}_{2} \mathrm{OsP}_{2}$ : C, 54.40; H, 7.43. Found: $\mathrm{C}, 54.76 ; \mathrm{H}, 7.16 .{ }^{1} \mathrm{H}$ $\operatorname{NMR}\left(300.13 \mathrm{MHz}, \mathrm{C}_{4} \mathrm{D}_{8} \mathrm{O}, 298 \mathrm{~K}\right): \delta 7.59\left(\mathrm{dd},{ }^{3} J_{\mathrm{HH}}=7.6,{ }^{4} J_{\mathrm{HH}}=\right.$ 1.2, $2 \mathrm{H}, \mathrm{CH}$-arom POP), 7.51 (m, $2 \mathrm{H}, \mathrm{CH}$-arom POP), 7.29 (dd, ${ }^{3} J_{\mathrm{HH}}=7.6,{ }^{3} J_{\mathrm{HH}}=7.5,2 \mathrm{H}, \quad \mathrm{CH}$-arom POP $), 2.48(\mathrm{~m}, 2 \mathrm{H}$, $\left.\mathrm{PCH}\left(\mathrm{CH}_{3}\right)_{2}\right), 2.36\left(\mathrm{~m}, 2 \mathrm{H}, \mathrm{PCH}\left(\mathrm{CH}_{3}\right)_{2}\right), 1.93\left(\mathrm{~s}, 3 \mathrm{H}, \mathrm{CH}_{3} \mathrm{POP}\right)$, 1.87-1.73 (10H, $\left.\mathrm{CH}_{2} \mathrm{BBN}\right), 1.39\left(\mathrm{~m}, 2 \mathrm{H}, \mathrm{CH}_{2} \mathrm{BBN}\right), 1.33(\mathrm{~s}, 3 \mathrm{H}$, $\mathrm{CH}_{3}$ POP), $1.22-1.14\left(12 \mathrm{H}, \mathrm{PCH}\left(\mathrm{CH}_{3}\right)_{2}\right), 1.10\left(\mathrm{dvt},{ }^{3} J_{\mathrm{HH}}=7.2, \mathrm{~N}\right.$ $\left.=14.9,6 \mathrm{H}, \mathrm{PCH}\left(\mathrm{CH}_{3}\right)_{2}\right), 0.86(\mathrm{br}, 2 \mathrm{H}, \mathrm{CH} \mathrm{BBN}), 0.76\left(\mathrm{dvt},{ }^{3} \mathrm{~J}_{\mathrm{HH}}=\right.$ 7.0, $\left.N=14.5,6 \mathrm{H}, \mathrm{PCH}\left(\mathrm{CH}_{3}\right)_{2}\right),-12.78\left(\mathrm{t},{ }^{3} J_{\mathrm{HP}}=11.8,3 \mathrm{H}, \mathrm{OsH}\right)$. ${ }^{1} \mathrm{H}$ NMR $\left(400.13 \mathrm{MHz}, \mathrm{C}_{7} \mathrm{D}_{8}, 193 \mathrm{~K}\right): \delta v_{\mathrm{A}}=-11.63$ and $v_{\mathrm{B}}=$ -13.61 (AB system, $\left.{ }^{2} J_{\mathrm{AB}}=98.5,2 \mathrm{H}, \mathrm{OsH}\right),-11.75(\mathrm{br}, 1 \mathrm{H}, \mathrm{OsH})$. ${ }^{13} \mathrm{C}\left\{{ }^{1} \mathrm{H}\right\}$-APT NMR $\left(75.47 \mathrm{MHz}, \mathrm{C}_{4} \mathrm{D}_{8} \mathrm{O}, 298 \mathrm{~K}\right): \delta 161.2(\mathrm{vt}, N=$ 13.4, $C$-arom POP), 134.2 (vt, $N=5.7, C$-arom POP), 130.3 (s, $\mathrm{CH}$ arom POP), 129.3 (vt, $N=28.5, C$-arom POP), 126.8 (s, $C H$-arom POP), 126.0 (vt, $\mathrm{N}=4.8, \mathrm{CH}$-arom POP), 35.7 (s, $\left.\mathrm{C}\left(\mathrm{CH}_{3}\right)_{2} \mathrm{POP}\right)$, $\left.35.2\left(\mathrm{~s}, \mathrm{CH}_{2} \mathrm{BBN} \text { ), } 34.0 \text { (s, C( } \mathrm{CH}_{3}\right)_{2} \mathrm{POP}\right), 32.5$ (br, $\left.\mathrm{CH} \mathrm{BBN}\right), 28.1$ (vt, $\left.\mathrm{N}=19.3, \mathrm{PCH}\left(\mathrm{CH}_{3}\right)_{2}\right), 25.5\left(\mathrm{~s}, \mathrm{CH}_{2} \mathrm{BBN}\right), 24.9$ (vt, $\mathrm{N}=32.3$, $\left.\mathrm{PCH}\left(\mathrm{CH}_{3}\right)_{2}\right), 23.8\left(\mathrm{~s}, \mathrm{C}\left(\mathrm{CH}_{3}\right)_{2} \mathrm{POP}\right), 20.6\left(\mathrm{~d},{ }^{2} J_{P C}=6.0\right.$, 
$\left.\operatorname{PCH}\left(\mathrm{CH}_{3}\right)_{2}\right), 20.4\left(\mathrm{~d},{ }^{2} J_{P C}=6.6, \operatorname{PCH}\left(\mathrm{CH}_{3}\right)_{2}\right), 20.0$ (s, PCH$\left.\left(\mathrm{CH}_{3}\right)_{2}\right) .{ }^{31} \mathrm{P}\left\{{ }^{1} \mathrm{H}\right\} \mathrm{NMR}\left(161.98 \mathrm{MHz}, \mathrm{C}_{7} \mathrm{D}_{8}, 293 \mathrm{~K}\right): 45.6$ (s, POP). ${ }^{11} \mathrm{~B}$ NMR $\left(96.30 \mathrm{MHz}, \mathrm{C}_{6} \mathrm{D}_{6}, 298 \mathrm{~K}\right): \delta 50.6(\mathrm{br}) . T_{1}(\mathrm{~min})(\mathrm{ms}$, $\left.\mathrm{OsH}, 400.13 \mathrm{MHz}, \mathrm{C}_{7} \mathrm{D}_{8}, 233 \mathrm{~K}\right): 77 \pm 4(-12.39 \mathrm{ppm})$.

Reaction of 2 with CO: Preparation of OsH(CO) ${ }_{2}\left(\mathrm{OBCy}_{2}\right)\left\{\kappa^{2}\right.$ $P, P$ - $\left.\left[x a n t\left(P^{i} P_{2}\right)_{2}\right]\right\}$ (4). A solution of $2(85 \mathrm{mg}, 0.103 \mathrm{mmol})$ in toluene $(5 \mathrm{~mL})$ was stirred for $24 \mathrm{~h}$ under $1 \mathrm{~atm}$ of $\mathrm{CO}$. The resulting solution was concentrated, and pentane $(1 \mathrm{~mL})$ at $0{ }^{\circ} \mathrm{C}$ was added to afford an off-white solid, which was washed twice with pentane (1 $\mathrm{mL}$ ) and dried under reduced pressure. Yield: $58 \mathrm{mg}$ (64\%). Anal. Calcd for $\mathrm{C}_{41} \mathrm{H}_{63} \mathrm{BO}_{4} \mathrm{OsP}_{2}$ : C, 55.77; $\mathrm{H}, 7.19$. Found: C, 55.90; $\mathrm{H}$, 7.30. IR (Toluene, $\mathrm{cm}^{-1}$ ): $\nu$ (CO) 1998 (s), $\nu$ (CO) $1914(\mathrm{~s}) .{ }^{1} \mathrm{H}$ NMR (300.13 MHz, $\left.\mathrm{C}_{6} \mathrm{D}_{6}, 298 \mathrm{~K}\right): \delta 7.21(\mathrm{~m}, 2 \mathrm{H}, \mathrm{CH}$-arom POP), 6.99-6.88 (4H, CH-arom POP), 2.63-2.28 (4H, $\left.\mathrm{PCH}\left(\mathrm{CH}_{3}\right)_{2}\right)$, $1.78-1.58\left(6 \mathrm{H}, \mathrm{CH}_{2} \mathrm{Cy}\right), 1.62\left(\mathrm{~s}, 3 \mathrm{H}, \mathrm{CH}_{3} \mathrm{POP}\right), 1.45-0.85(36 \mathrm{H}$, $\left.\mathrm{CH} \mathrm{Cy}, \mathrm{CH}_{2} \mathrm{Cy}, \mathrm{PCH}\left(\mathrm{CH}_{3}\right)_{2}\right), 1.16\left(\mathrm{~s}, 3 \mathrm{H}, \mathrm{CH}_{3} \mathrm{POP}\right), 0.35(\mathrm{~m}, 4 \mathrm{H}$, $\left.\mathrm{CH}_{2}\right),-6.51(\mathrm{~m}, 1 \mathrm{H}, \mathrm{OsH}) .{ }^{1} \mathrm{H}$ NMR $\left(400.13 \mathrm{MHz}, \mathrm{C}_{7} \mathrm{D}_{8}, 203 \mathrm{~K}\right)$ : $-6.30\left(\mathrm{dd},{ }^{2} \mathrm{~J}_{\mathrm{HH}}=33.6,{ }^{2} \mathrm{~J}_{\mathrm{HH}}=115.1,1 \mathrm{H}, \mathrm{OsH}\right) .{ }^{13} \mathrm{C}\left\{{ }^{1} \mathrm{H}\right\} \mathrm{NMR}$ $\left(75.48 \mathrm{MHz}, \mathrm{C}_{6} \mathrm{D}_{6}, 298 \mathrm{~K}\right): \delta 185.7\left(\mathrm{~d},{ }^{2} J_{\mathrm{CP}}=98.0, \mathrm{CO}\right), 181.9-$ $181.7(\mathrm{CO}), 156.2\left(\mathrm{~d},{ }^{2} J_{\mathrm{CP}}=6.0, \mathrm{C}\right.$-arom POP), $155.4\left(\mathrm{~d},{ }^{2} J_{\mathrm{CP}}=6.2\right.$, $C$-arom POP), 134.6 (vt, $N=3.8, C$-arom POP), 134.0 (vt, $N=3.6$, $\mathrm{C}$-arom POP), 131.3 (s, $\mathrm{CH}$-arom POP), 131.0 (s, $\mathrm{CH}$-arom POP), 126.1 (s, CH-arom POP), 125.6 (s, CH-arom POP), 123.5 (s, CHarom POP), 123.4 (s, $\mathrm{CH}$-arom POP), $118.2\left(\mathrm{~d},{ }^{1} J_{\mathrm{CP}}=26.9, \mathrm{C}\right.$-arom POP), $113.7\left(\mathrm{~d},{ }^{1} J_{\mathrm{CP}}=28.6, \mathrm{C}\right.$-arom POP $), 35.9\left(\mathrm{~s}, \mathrm{C}\left(\mathrm{CH}_{3}\right)_{2} \mathrm{POP}\right)$, 35.0 (br, $\mathrm{CH}-\mathrm{Cy}), 32.0\left(\mathrm{~s}, \mathrm{C}\left(\mathrm{CH}_{3}\right)_{2} \mathrm{POP}\right), 30.2\left(\mathrm{~d},{ }^{1} \mathrm{~J}_{\mathrm{CP}}=16.6\right.$, $\left.\mathrm{PCH}\left(\mathrm{CH}_{3}\right)_{2}\right)$, 28.7, 28.7, 28.6, 28.5, 27.8 (all s, $\mathrm{CH}_{2}-\mathrm{Cy}$ ), 27.5 (d, $\left.{ }^{1} J_{\mathrm{CP}}=22.3, \quad \mathrm{PCH}\left(\mathrm{CH}_{3}\right)_{2}\right), 23.9\left(\mathrm{~m}, \mathrm{PCH}\left(\mathrm{CH}_{3}\right)_{2}\right), 23.3(\mathrm{~m}$, $\left.\mathrm{PCH}\left(\mathrm{CH}_{3}\right)_{2}\right), 22.6\left(\mathrm{~s}, \mathrm{C}\left(\mathrm{CH}_{3}\right)_{2} \mathrm{POP}\right), 20.6\left(\mathrm{~d},{ }^{2} J_{\mathrm{CP}}=4.1\right.$, $\left.\operatorname{PCH}\left(\mathrm{CH}_{3}\right)_{2}\right), 19.4\left(\mathrm{~m}, \mathrm{PCH}\left(\mathrm{CH}_{3}\right)_{2}\right), 19.1\left(\mathrm{~s}, \mathrm{PCH}\left(\mathrm{CH}_{3}\right)_{2}\right), 18.8$ $\left(\mathrm{d},{ }^{2} J_{\mathrm{CP}}=6.3, \mathrm{PCH}\left(\mathrm{CH}_{3}\right)_{2}\right), 18.6\left(\mathrm{br}, \mathrm{PCH}\left(\mathrm{CH}_{3}\right)_{2}\right), 18.1\left(\mathrm{~d},{ }^{2} J_{\mathrm{CP}}=\right.$ 2.2, $\left.\operatorname{PCH}\left(\mathrm{CH}_{3}\right)_{2}\right), 18.0\left(\mathrm{~d},{ }^{2} J_{\mathrm{CP}}=4.3, \operatorname{PCH}\left(\mathrm{CH}_{3}\right)_{2}\right), 17.7(\mathrm{~m}$, $\left.\mathrm{PCH}\left(\mathrm{CH}_{3}\right)_{2}\right) .{ }^{13} \mathrm{C}\left\{{ }^{1} \mathrm{H}\right\}$ NMR $\left(100.62 \mathrm{MHz}, \mathrm{C}_{7} \mathrm{D}_{8}, 203 \mathrm{~K}\right): \delta 186.0$ $\left(\mathrm{dd},{ }^{2} J_{\mathrm{CP}}=99.8,{ }^{2} J_{\mathrm{CP}}=1.0, \mathrm{CO}\right), 181.8\left(\mathrm{dd},{ }^{2} J_{\mathrm{CP}}=10.5,{ }^{2} J_{\mathrm{CP}}=2.1\right.$, CO), ${ }^{31} \mathrm{P}\left\{{ }^{1} \mathrm{H}\right\}$ NMR $\left(121.50 \mathrm{MHz}, \mathrm{C}_{6} \mathrm{D}_{6}, 298 \mathrm{~K}\right): \delta 3.2$ (br, POP). ${ }^{31} \mathrm{P}\left\{{ }^{1} \mathrm{H}\right\}$ NMR $\left(161.98 \mathrm{MHz}, \mathrm{C}_{7} \mathrm{D}_{8}, 203 \mathrm{~K}\right): 3.4\left(\mathrm{~d},{ }^{2} J_{\mathrm{PP}}=26.2\right.$, POP), $1.5\left(\mathrm{~d},{ }^{2} J_{\mathrm{PP}}=26.2\right.$, POP). ${ }^{11} \mathrm{~B}$ NMR $\left(96.30 \mathrm{MHz}, \mathrm{C}_{6} \mathrm{D}_{6}, 298\right.$ $\mathrm{K}): \delta 50.0(\mathrm{br})$. Crystals suitable for X-ray diffraction analysis were obtained from a concentrated solution of the complex in benzene.

Reaction of 3 with CO: Formation of $\mathrm{OsH}(\mathrm{CO})_{2}(\mathrm{OBBN})\left\{\boldsymbol{\kappa}^{2}-\right.$ $P, P$ - $\left[\right.$ xant $\left.\left.\left(\mathrm{P}^{i} \mathrm{Pr}_{2}\right)_{2}\right]\right\}$ (5). Complex $3(25 \mathrm{mg}, 0.035 \mathrm{mmol})$ in toluene$d_{8}(0.5 \mathrm{~mL})$ was placed in a NMR tube equipped with a Teflon screw cap at room temperature under $1 \mathrm{~atm}$ of CO. After $24 \mathrm{~h}$, a mixture of 5 and $\mathbf{6}$ was formed in a 1:1 ratio. Selected spectroscopic data for 5: ${ }^{1} \mathrm{H}$ NMR $\left(300.13 \mathrm{MHz}, \mathrm{C}_{7} \mathrm{D}_{8}, 298 \mathrm{~K}\right):-6.69\left(\mathrm{dd},{ }^{2} J_{\mathrm{HP}}=31.7,{ }^{2} J_{\mathrm{HP}}=\right.$ $110.5,1 \mathrm{H}, \mathrm{OsH}) .{ }^{1} \mathrm{H}$ NMR $\left(400.13 \mathrm{MHz}, \mathrm{C}_{7} \mathrm{D}_{8}, 203 \mathrm{~K}\right):-5.64(\mathrm{dd}$, $\left.{ }^{2} J_{\mathrm{HP}}=29.4,{ }^{2} J_{\mathrm{HP}}=99.0,1 \mathrm{H}, \mathrm{OsH}\right),-6.31\left(\mathrm{dd},{ }^{2} J_{\mathrm{HP}}=32.5,{ }^{2} J_{\mathrm{HP}}=\right.$ 107.5, 1H, OsH $).{ }^{13} \mathrm{C}\left\{{ }^{1} \mathrm{H}\right\}$ NMR $\left(75.48 \mathrm{MHz}, \mathrm{C}_{7} \mathrm{D}_{8}, 298 \mathrm{~K}\right): \delta 185.4$ $\left(\mathrm{dd},{ }^{2} J_{\mathrm{CP}}=98.0,{ }^{2} J_{\mathrm{CP}}=3.3, \mathrm{CO}\right), 182.1\left(\mathrm{dd},{ }^{2} J_{\mathrm{CP}}=10.3,{ }^{2} J_{\mathrm{CP}}=4.5\right.$, CO). ${ }^{31} \mathrm{P}\left\{{ }^{1} \mathrm{H}\right\}$ NMR (121.49 MHz, $\left.\mathrm{C}_{7} \mathrm{D}_{8}, 298 \mathrm{~K}\right): \delta 10.8$ (br, POP). ${ }^{31} \mathrm{P}\left\{{ }^{1} \mathrm{H}\right\}$ NMR $\left(161.98 \mathrm{MHz}, \mathrm{C}_{7} \mathrm{D}_{8}, 203 \mathrm{~K}\right): 20.7\left(\mathrm{~d},{ }^{2} J_{\mathrm{PP}}=24.5\right.$, POP), $13.1\left(\mathrm{~d},{ }^{2} J_{\mathrm{PP}}=24.5\right.$, POP $), 12.0\left(\mathrm{~d},{ }^{2} J_{\mathrm{PP}}=24.5\right.$, POP $), 11.4(\mathrm{~d}$, ${ }^{2} J_{\mathrm{PP}}=24.5$, POP $) .{ }^{11} \mathrm{~B}$ NMR $\left(96.29 \mathrm{MHz}, \mathrm{C}_{7} \mathrm{D}_{8}, 298 \mathrm{~K}\right): \delta 51.3(\mathrm{br})$.

Preparation of $\mathrm{Os}(\mathrm{CO})_{3}\left\{\kappa^{2}-P, P-\left[x a n t\left(\mathrm{P}^{i} \mathrm{Pr}_{2}\right)_{2}\right]\right\}$ (6). A solution of $4(150 \mathrm{mg} ; 0.170 \mathrm{mmol})$ in toluene $(5 \mathrm{~mL})$ was placed in a Schlenk tube provided equipped with a Teflon screw cap. The solution was stirred at $110{ }^{\circ} \mathrm{C}$ under $1 \mathrm{~atm}$ of $\mathrm{CO}$ for 4 days. After this time, a dark powder and a yellow solution were formed. The yellow solution was filtered, and the solvent was evaporated to obtain a yellow oil. Its treatment with methanol $(2 \mathrm{~mL})$ at $-50{ }^{\circ} \mathrm{C}$ afforded a yellow solid which was dried under reduced pressure. Yield: $50 \mathrm{mg}$ (41\%). Anal. Calcd for $\mathrm{C}_{30} \mathrm{H}_{40} \mathrm{O}_{4} \mathrm{OsP}_{2}$ : C, 50.27; $\mathrm{H}, 5.62$. Found: C, 49.93; $\mathrm{H}$, 5.81. IR (Toluene, $\mathrm{cm}^{-1}$ ): $\nu$ (CO) $2003(\mathrm{w}), \nu$ (CO) $1916(\mathrm{~s}), \nu$ (CO) 1900 (s). ${ }^{1} \mathrm{H}$ NMR (300.13 MHz, $\left.\mathrm{CD}_{2} \mathrm{Cl}_{2}, 298 \mathrm{~K}\right): \delta 7.51$ (dd, ${ }^{3} J_{\mathrm{HH}}=7.3,{ }^{4} J_{\mathrm{HH}}=1.7,2 \mathrm{H}, \mathrm{CH}$-arom POP $), 7.28(\mathrm{~m}, 2 \mathrm{H}, \mathrm{CH}$-arom POP), $7.22\left(\mathrm{dd},{ }^{3} J_{\mathrm{HH}}=7.7,{ }^{3} \mathrm{~J}_{\mathrm{HH}}=7.3,2 \mathrm{H}, \mathrm{CH}\right.$-arom POP $), 2.50(\mathrm{~m}$, $\left.4 \mathrm{H}, \mathrm{PCH}\left(\mathrm{CH}_{3}\right)_{2}\right), 1.57\left(\mathrm{~s}, 6 \mathrm{H}, \mathrm{CH}_{3} \mathrm{POP}\right), 1.11\left(\mathrm{dvt},{ }^{3} J_{\mathrm{HH}}=6.9, \mathrm{~N}=\right.$ 16.6, $\left.12 \mathrm{H}, \mathrm{PCH}\left(\mathrm{CH}_{3}\right)_{2}\right), 1.02\left(\mathrm{dvt},{ }^{3} J_{\mathrm{HH}}=6.8, \mathrm{~N}=15.3,12 \mathrm{H}\right.$, $\left.\mathrm{PCH}\left(\mathrm{CH}_{3}\right)_{2}\right) .{ }^{31} \mathrm{P}\left\{{ }^{1} \mathrm{H}\right\}$ NMR $\left(121.50 \mathrm{MHz}, \mathrm{CD}_{2} \mathrm{Cl}_{2}, 298 \mathrm{~K}\right): 4.5(\mathrm{~s}$,
POP). Crystals suitable for X-ray diffraction analysis were obtained by slow diffusion of pentane into a toluene solution of the complex at $-30{ }^{\circ} \mathrm{C}$.

Reaction of 1 with CO: Formation of $\mathrm{OsH}_{2} \mathrm{CO}\left\{\kappa^{3}-P, O, P-\right.$ [xant $\left(\mathrm{P}^{i} \mathrm{Pr}_{2}\right)_{2}$ ] $\}$ (7). A solution of $\mathbf{1}(0.100 \mathrm{~g}, 0.153 \mathrm{mmol})$ in toluene $(5 \mathrm{~mL})$ was stirred under $1 \mathrm{~atm}$ of $\mathrm{CO}$ for $24 \mathrm{~h}$. The resulted solution was concentrated, and pentane $(2 \mathrm{~mL})$ at $0{ }^{\circ} \mathrm{C}$ was added to afford a yellow solid which was washed with pentane $(2 \times 2 \mathrm{~mL})$ and dried under reduced pressure. Yield: $50 \mathrm{mg}(49 \%)$. The solid was characterized as 7 by comparison of its spectroscopic data with those reported in ref $8 \mathrm{~h}$.

Reaction of 7 with CO: Formation of $\mathrm{OsH}_{2}(\mathrm{CO})_{2}\left\{\kappa^{2}-P, P-\right.$ [xant $\left.\left.\left(\mathrm{P}^{i} \mathrm{Pr}_{2}\right)_{2}\right]\right\}$ (8). A toluene- $d_{8}$ solution of $7(40 \mathrm{mg}, 0.06 \mathrm{mmol}$, in $0.6 \mathrm{~mL}$ ) was placed in a NMR tube bearing a Teflon screw cap under $1 \mathrm{~atm}$ of $\mathrm{CO}$ and heated at $110^{\circ} \mathrm{C}$ for $8 \mathrm{~h}$. After that, a mixture of 8 and 6 was formed in a 3:1 molar ratio. Spectroscopic data for $8:{ }^{1} \mathrm{H}$ NMR $\left(300.13 \mathrm{MHz}, \mathrm{C}_{7} \mathrm{D}_{8}, 298 \mathrm{~K}\right): \delta 7.10\left(\mathrm{~d},{ }^{3} J_{\mathrm{HP}}=7.5,2 \mathrm{H}, \mathrm{CH}-\right.$ arom POP $), 6.96(\mathrm{~m}, 2 \mathrm{H}, \mathrm{CH}$-arom POP $), 6.93(\mathrm{~m}, 2 \mathrm{H}, \mathrm{CH}$-arom POP), $2.52\left(\mathrm{~m}, 1 \mathrm{H}, \mathrm{PCH}\left(\mathrm{CH}_{3}\right)_{2}\right), 2.36\left(\mathrm{~m}, 1 \mathrm{H}, \mathrm{PCH}\left(\mathrm{CH}_{3}\right)_{2}\right), 2.22$ $\left(\mathrm{m}, 1 \mathrm{H}, \mathrm{PCH}\left(\mathrm{CH}_{3}\right)_{2}\right), 2.18\left(\mathrm{~m}, 1 \mathrm{H}, \mathrm{PCH}\left(\mathrm{CH}_{3}\right)_{2}\right), 1.40\left(\mathrm{~s}, 3 \mathrm{H}, \mathrm{CH}_{3}\right.$ POP), $1.31\left(\mathrm{dd},{ }^{3} J_{\mathrm{HH}}=7.3,{ }^{3} J_{\mathrm{HP}}=15.0,3 \mathrm{H}, \mathrm{PCH}\left(\mathrm{CH}_{3}\right)_{2}\right), 1.28-1.10$ $\left(\mathrm{m}, 15 \mathrm{H}, \mathrm{PCH}\left(\mathrm{CH}_{3}\right)_{2}\right), 1.20\left(\mathrm{~s}, 3 \mathrm{H}, \mathrm{CH}_{3} \mathrm{POP}\right), 0.97\left(\mathrm{dd},{ }^{3} J_{\mathrm{HH}}=7.1\right.$, $\left.{ }^{3} J_{\mathrm{HP}}=12.8,3 \mathrm{H}, \mathrm{PCH}\left(\mathrm{CH}_{3}\right)_{2}\right), 0.89\left(\mathrm{dd},{ }^{3} J_{\mathrm{HH}}=7.1,{ }^{3} J_{\mathrm{HP}}=13.8,3 \mathrm{H}\right.$, $\left.\mathrm{PCH}\left(\mathrm{CH}_{3}\right)_{2}\right),-7.92\left(\mathrm{ddd},{ }^{2} J_{\mathrm{HH}}=6.1,{ }^{2} J_{\mathrm{HP}}=19.6,{ }^{2} J_{\mathrm{HP}}=26.4,1 \mathrm{H}\right.$, $\mathrm{OsH}),-10.01\left(\mathrm{ddd},{ }^{2} \mathrm{~J}_{\mathrm{HH}}=6.1,{ }^{2} \mathrm{~J}_{\mathrm{HP}}=35.5,{ }^{2} J_{\mathrm{HP}}=67.5,1 \mathrm{H}, \mathrm{OsH}\right)$. ${ }^{13} \mathrm{C}\left\{{ }^{1} \mathrm{H}\right\}$ NMR $\left(75.48 \mathrm{MHz}, \mathrm{C}_{7} \mathrm{D}_{8}, 298 \mathrm{~K}\right): \delta 188.0\left(\mathrm{dd},{ }^{2} J_{\mathrm{CP}}=3.4\right.$, $\left.{ }^{2} J_{\mathrm{CP}}=74.1, \mathrm{CO}\right), 186.0\left(\mathrm{dd},{ }^{2} J_{\mathrm{CP}}=3.6,{ }^{2} J_{\mathrm{CP}}=10.0, \mathrm{CO}\right), 156.0(\mathrm{~d}$, ${ }^{2} J_{\mathrm{CP}}=6.7, \mathrm{C}$-arom POP), $155.8\left(\mathrm{~d},{ }^{2} J_{\mathrm{CP}}=6.9, \mathrm{C}\right.$-arom POP $), 134.8$ $\left(\mathrm{d},{ }^{3} J_{\mathrm{CP}}=3.0, C\right.$-arom POP $), 134.4\left(\mathrm{~d},{ }^{3} J_{\mathrm{CP}}=3.0, C\right.$-arom POP $)$, 129.4 (s, CH-arom POP), 125.8 (s, CH-arom POP), 125.8 (s, $\mathrm{CH}-$ arom POP), 125.5 (s, CH-arom POP), 123.0 (s, $\mathrm{CH}$-arom POP), 123.0 (s, $\mathrm{CH}$-arom POP), 122.9 (s, $\mathrm{CH}$-arom POP), 122.9 (s, $\mathrm{CH}$ arom POP), $122.4\left(\mathrm{~d},{ }^{1} J_{\mathrm{CP}}=26.4, C\right.$-arom POP $), 121.1\left(\mathrm{~d},{ }^{1} J_{\mathrm{CP}}=\right.$ 27.9, $\mathrm{C}$-arom POP), 36.1 (s, $\left.\mathrm{C}\left(\mathrm{CH}_{3}\right)_{2} \mathrm{POP}\right), 30.6\left(\mathrm{~s}, \mathrm{C}\left(\mathrm{CH}_{3}\right)_{2} \mathrm{POP}\right)$, $30.0\left(\mathrm{~d},{ }^{1} J_{\mathrm{CP}}=25.2, \mathrm{PCH}\left(\mathrm{CH}_{3}\right)_{2}\right), 29.1\left(\mathrm{~d},{ }^{1} J_{\mathrm{CP}}=21.5, \mathrm{PCH}\left(\mathrm{CH}_{3}\right)_{2}\right)$, $26.5\left(\mathrm{dd},{ }^{3} J_{\mathrm{CP}}=2.5,{ }^{1} J_{\mathrm{CP}}=27.8, \mathrm{PCH}\left(\mathrm{CH}_{3}\right)_{2}\right), 25.4\left(\mathrm{dd},{ }^{3} J_{\mathrm{CP}}=4.8\right.$, $\left.{ }^{1} J_{\mathrm{CP}}=35.4, \mathrm{PCH}\left(\mathrm{CH}_{3}\right)_{2}\right), 24.6\left(\mathrm{~s}, \mathrm{C}\left(\mathrm{CH}_{3}\right)_{2} \mathrm{POP}\right), 20.6(\mathrm{~s}$, $\left.\operatorname{PCH}\left(\mathrm{CH}_{3}\right)_{2}\right), 20.3\left(\mathrm{~s}, \mathrm{PCH}\left(\mathrm{CH}_{3}\right)_{2}\right), 19.8\left(\mathrm{~d},{ }^{2} J_{\mathrm{CP}}=1.7, \mathrm{PCH}-\right.$ $\left.\left(\mathrm{CH}_{3}\right)_{2}\right), 18.8\left(\mathrm{~d},{ }^{2} J_{\mathrm{CP}}=5.0, \mathrm{PCH}\left(\mathrm{CH}_{3}\right)_{2}\right), 18.7\left(\mathrm{dd},{ }^{4} J_{\mathrm{CP}}=1.9,{ }^{2} J_{\mathrm{CP}}=\right.$ 2.8, $\left.\operatorname{PCH}\left(\mathrm{CH}_{3}\right)_{2}\right), 18.1\left(\mathrm{~s}, \operatorname{PCH}\left(\mathrm{CH}_{3}\right)_{2}\right), 18.0\left(\mathrm{~d},{ }^{2} J_{\mathrm{CP}}=2.3\right.$, $\left.\mathrm{PCH}\left(\mathrm{CH}_{3}\right)_{2}\right), 17.6\left(\mathrm{~d},{ }^{2} J_{\mathrm{CP}}=3.0, \mathrm{PCH}\left(\mathrm{CH}_{3}\right)_{2}\right) .{ }^{31} \mathrm{P}\left\{{ }^{1} \mathrm{H}\right\}$ NMR $\left(121.49 \mathrm{MHz}, \mathrm{C}_{7} \mathrm{D}_{8}, 298 \mathrm{~K}\right): 4.2\left(\mathrm{~d},{ }^{2} J_{\mathrm{PP}}=25.6\right.$, POP $), 1.9\left(\mathrm{~d},{ }^{2} J_{\mathrm{PP}}=\right.$ 25.6, POP).

\section{ASSOCIATED CONTENT}

\section{Supporting Information}

The Supporting Information is available free of charge on the ACS Publications website at DOI: 10.1021/acs.organomet.8b00727.

Instrumental methods; NMR spectra of complexes 2, 3, 4, 5, 6, and 8; IR spectra of complexes 4 and 6; structural analysis of complexes 2, 4, and 6; and computational details (PDF)

Cartesian coordinates of the optimized structures (XYZ)

\section{Accession Codes}

CCDC 1871559-1871561 contain the supplementary crystallographic data for this paper. These data can be obtained free of charge via www.ccdc.cam.ac.uk/data_request/cif, by emailing data_request@ccdc.cam.ac.uk, or by contacting The Cambridge Crystallographic Data Centre, 12 Union Road, Cambridge CB2 1EZ, UK; fax: +44 1223336033.

\section{AUTHOR INFORMATION}

\section{Corresponding Authors}

*E-mail: antonio.antinolo@uclm.es.

*E-mail: maester@unizar.es. 


\section{ORCID}

Antonio Antiñolo: 0000-0002-4417-6417

Miguel A. Esteruelas: 0000-0002-4829-7590

Cristina García-Yebra: 0000-0002-5545-5112

Jaime Martín: 0000-0003-0909-3509

Enrique Oñate: 0000-0003-2094-719X

\section{Present Address}

${ }^{\S}$ C.G.-Y.: Departamento de Química Orgánica y Química Inorgánica, Universidad de Alcalá, 28871 Alcalá de Henares, Spain.

Notes

The authors declare no competing financial interest.

\section{ACKNOWLEDGMENTS}

Financial support from the MINECO of Spain (Projects CTQ2017-82935-P, CTQ2016-77614-P and Red de Excelencia Consolider CTQ2016-81797-REDC), the Diputacion General de Aragón (E06 17R), FEDER, and the European Social Fund is acknowledged. A.R. acknowledges a postdoctoral contract funded by the "Plan Propio de I $+\mathrm{D}+\mathrm{i}$ " of the Universidad de Castilla-La Mancha.

\section{REFERENCES}

(1) (a) Roesky, H. W.; Singh, S.; Yusuff, K. K.M.; Maguire, J. A.; Hosmane, N. S. Organometallic Hydroxides of Transition Elements. Chem. Rev. 2006, 106, 3813-3843. (b) Nelson, D. J.; Nolan, S. P. Hydroxide Complexes of the Late Transition Metals: Organometallic Chemistry and Catalysis. Coord. Chem. Rev. 2017, 353, 278-294.

(2) (a) Gould, R. O.; Jones, C. L.; Stephenson, T. A.; Tocher, D. A. Structural Characterization of Hydroxo-Bridged Arene-Ruthenium and -Osmium Complexes: Further Reactions of Hydroxo-Bridged Complexes. J. Organomet. Chem. 1984, 264, 365-378. (b) Cabeza, J. A.; Mann, B. E.; Maitlis, P. M.; Brevard, C. The Synthesis of DiNuclear and Tetra-Nuclear $p$-Cymene-Osmium Hydride Complexes Characterization by ${ }^{1} \mathrm{H}\left({ }^{187} \mathrm{Os}\right)$ Reverse INEPT Two-Dimensional Nuclear Magnetic-Resonance Spectroscopy. J. Chem. Soc., Dalton Trans. 1988, 629-634. (c) Esteruelas, M. A.; García-Yebra, C.; Oliván, M.; Oñate, E. Reaction of a Cationic Osmium(IV) Dihydride with Ethylene: Formation and Structure of the Novel Tetraethylene Dimer Complex $\left[\left\{\left(\mathrm{P}^{\mathrm{i}} \mathrm{Pr}_{3}\right)\left(\eta^{2}-\mathrm{C}_{2} \mathrm{H}_{4}\right)_{2} \mathrm{Os}\right\}_{2}(\mu-\mathrm{OH})_{2}\left(\mu-\mathrm{O}_{2} \mathrm{CCH}_{3}\right)\right] \mathrm{BF}_{4}$. Organometallics 2000, 19, 3260-3262. (d) Peacock, A. F.A.; Habtemariam, A.; Fernández, R.; Walland, V.; Fabbiani, F. P.A.; Parsons, S.; Aird, R. E.; Jodrell, D. I.; Sadler, P. J. Tuning the Reactivity of Osmium(II) and Ruthenium(II) Arene Complexes under Physiological Conditions. J. Am. Chem. Soc. 2006, 128, 17391748 .

(3) (a) Wu, A.; Dehestani, A.; Saganic, E.; Crevier, T. J.; Kaminsky, W.; Cohen, D. E.; Mayer, J. M. Reactions of Tp-Os Nitrido Complexes with the Nucleophiles Hydroxide and Thiosulfate. Inorg. Chim. Acta 2006, 359, 2842-2849. (b) Kiefer, A. M.; Giles, J. A.; Shapley, P. A. Synthesis, Structure, and Reactivity of Organometallic Osmium(VI) Hydroxo Compounds. Organometallics 2007, 26, 18811887.

(4) (a) Castarlenas, R.; Esteruelas, M. A.; Oñate, E. Preparation, Xray Structure, and Reactivity of an Osmium-Hydroxo Complex Stabilized by an N-Heterocyclic Carbene Ligand: A Base-Free Catalytic Precursor for Hydrogen Transfer from 2-Propanol to Aldehydes. Organometallics 2008, 27, 3240-3247. (b) Buil, M. L.; Cadierno, V.; Esteruelas, M. A.; Gimeno, J.; Herrero, J.; Izquierdo, S.; Oñate, E. Selective Hydration of Nitriles to Amides Promoted by an Os-NHC Catalyst: Formation and X-ray Characterization of $\kappa^{2}$ Amidate Intermediates. Organometallics 2012, 31, 6861-6867. (c) Buil, M. L.; Esteruelas, M. A.; Herrero, J.; Izquierdo, S.; Pastor, I. M.; Yus, M. Osmium Catalyst for the Borrowing Hydrogen Methodology: $\alpha$-Alkylation of Arylacetonitriles and Methyl Ketones. ACS Catal. 2013, 3, 2072-2075.
(5) (a) Gotzig, J.; Werner, R.; Werner, H. Basic Metals: 53. Ruthenium- and Osmium-Complexes with Dimethylphosphinomethanide-Anion as Ligands. J. Organomet. Chem. 1985, 290, 99-114. (b) Edwards, A. J.; Elipe, S.; Esteruelas, M. A.; Lahoz, F. J.; Oro, L. A.; Valero, C. Synthesis and Reactivity of the Unusual Five-Coordinate Hydrido-Hydroxo Complex $\mathrm{OsH}(\mathrm{OH})(\mathrm{CO})\left(\mathrm{P}^{\mathrm{i}} \mathrm{Pr}_{3}\right)_{2}$. Organometallics 1997, 16, 3828-3836. (c) Renkema, K. B.; Huffman, J. C.; Caulton, K. G. Characterization and Structure of $\mathrm{OsH}(\mathrm{OH})(\mathrm{CO})$ $\left(\mathrm{PBu}_{2} \mathrm{Me}\right)^{t} \mathrm{Bu}_{2}$. Polyhedron 1999, 18, 2575-2578. (d) Prokopchuk, D. E.; Collado, A.; Lough, A. J.; Morris, R. H. Structural Properties of trans Hydrido-Hydroxo $\mathrm{M}(\mathrm{H})(\mathrm{OH})\left(\mathrm{NH}_{2} \mathrm{CMe}_{2} \mathrm{CMe}_{2} \mathrm{NH}_{2}\right)\left(\mathrm{PPh}_{3}\right)_{2}$ $(\mathrm{M}=\mathrm{Ru}$, Os $)$ Complexes and their Proton Exchange Behaviour with Water in Solution. Dalton Trans. 2013, 42, 10214-10220. (e) Buil, M. L.; Cardo, J. J.F.; Esteruelas, M. A.; Fernández, I.; Oñate, E. Hydroboration and Hydrogenation of an Osmium-Carbon Triple Bond: Osmium Chemistry of a Bis- $\sigma$-Borane. Organometallics 2015, 34, 547-550. (f) Esteruelas, M. A.; García-Yebra, C.; Martín, J.; Oñate, E. Dehydrogenation of Formic Acid Promoted by a Trihydride-Hydroxo-Osmium (IV) Complex: Kinetics and Mechanism. ACS Catal. 2018, 8, 11314-11323.

(6) Ozerov, O. V. Oxidative Addition of Water to Transition Metal Complexes. Chem. Soc. Rev. 2009, 38, 83-88.

(7) Pincer Compounds: Chemistry and Applications; 1st Edition; Morales-Morales, D., Ed.; Elsevier: Amsterdam, 2018.

(8) For complexes of platinum group metals bearing this ligand, see: (a) Asensio, G.; Cuenca, A. B.; Esteruelas, M. A.; Medio-Simón, M.; Oliván, M.; Valencia, M. Osmium(III) Complexes with POP Pincer Ligands: Preparation from Commercially Available $\mathrm{OsCl}_{3} \cdot 3 \mathrm{H}_{2} \mathrm{O}$ and Their X-ray Structures. Inorg. Chem. 2010, 49, 8665-8667. (b) Esteruelas, M. A.; Oliván, M.; Vélez, A. Xantphos-Type Complexes of Group 9: Rhodium versus Iridium. Inorg. Chem. 2013, 52, 5339-5349. (c) Alós, J.; Bolaño, T.; Esteruelas, M. A.; Oliván, M.; Oñate, E.; Valencia, M. POP-Pincer Osmium-Polyhydrides: Head-to-Head ( $Z$ )-Dimerization of Terminal Alkynes. Inorg. Chem. 2013, 52, 6199-6213. (d) Esteruelas, M. A.; Oliván, M.; Vélez, A. POP-Pincer Silyl Complexes of Group 9: Rhodium versus Iridium. Inorg. Chem. 2013, 52, 12108-12119. (e) Alós, J.; Bolaño, T.; Esteruelas, M. A.; Oliván, M.; Oñate, E.; Valencia, M. POP-Pincer Ruthenium Complexes: $\mathrm{d}^{6}$ Counterparts of Osmium $\mathrm{d}^{4}$ Species. Inorg. Chem. 2014, 53, 1195-1209. (f) Esteruelas, M. A.; Oliván, M.; Vélez, A. POP-Rhodium-Promoted C-H and B-H Bond Activation and C-B Bond Formation. Organometallics 2015, 34, 1911-1924. (g) Esteruelas, M. A.; Oliván, M.; Vélez, A. Conclusive Evidence on the Mechanism of the Rhodium-Mediated Decyanative Borylation. J. Am. Chem. Soc. 2015, 137, 12321-12329. (h) Alós, J.; Esteruelas, M. A.; Oliván, M.; Oñate, E.; Puylaert, P. C-H Bond Activation Reactions in Ketones and Aldehydes Promoted by POP-Pincer Osmium and Ruthenium Complexes. Organometallics 2015, 34, 4908-4921. (i) Esteruelas, M. A.; Nolis, P.; Oliván, M.; Oñate, E.; Vallribera, A.; Vélez, A. Ammonia Borane Dehydrogenation Promoted by a Pincer-Square-Planar Rhodium(I) Monohydride: A Stepwise Hydrogen Transfer from the Substrate to the Catalyst. Inorg. Chem. 2016, 55, 7176-7181. (j) Esteruelas, M. A.; García-Yebra, C.; Martín, J.; Oñate, E. mer, fac, and Bidentate Coordination of an Alkyl-POP Ligand in the Chemistry of Nonclassical Osmium Hydrides. Inorg. Chem. 2017, 56, 676-683. (k) Curto, S. G.; Esteruelas, M. A.; Oliván, M.; Oñate, E.; Vélez, A. Selective C-Cl Bond Oxidative Addition of Chloroarenes to a POP-Rhodium Complex. Organometallics 2017, 36, 114-128. (1) Esteruelas, M. A.; Fernández, I.; García-Yebra, C.; Martín, J.; Oñate, E. Elongated $\sigma$-Borane versus $\sigma$-Borane in PincerPOP-Osmium Complexes. Organometallics 2017, 36, 2298-2307. (m) Curto, S. G.; Esteruelas, M. A.; Oliván, M.; Oñate, E.; Vélez, A. $\beta$-Borylalkenyl Z-E Isomerization in Rhodium-Mediated Diboration of Nonfunctionalized Internal Alkynes. Organometallics 2018, 37, 1970-1978. (n) Esteruelas, M. A.; Oliván, M. Osmium Complexes with POP Pincer Ligands. In Pincer Compounds: Chemistry and Applications, 1st Edition.; Morales-Morales, D., Ed.; Elsevier: Amsterdam, 2018. 
(9) See, for example: Cuesta, L.; Hevia, E.; Morales, D.; Pérez, J.; Riera, L.; Miguel, D. Reactivity of Molybdenum and Rhenium Hydroxo Complexes toward Organic Electrophiles: Reactions that Afford Carboxylato Products. Organometallics 2006, 25, 1717-1722. (10) Buil, M. L.; Cardo, J. J.F.; Esteruelas, M. A.; Oñate, E. Dehydrogenative Addition of Aldehydes to a Mixed NHC-OsmiumPhosphine Hydroxide Complex: Formation of Carboxylate Derivatives. Organometallics 2016, 35, 2171-2173.

(11) (a) Cole, S. C.; Coles, M. P.; Hitchcock, P. B. A Step too Far? Assessment of the Boroxide Ligand in Ring-Opening Polymerization. Organometallics 2004, 23, 5159-5168. (b) Cole, S. C.; Coles, M. P.; Hitchcock, P. B. Boroxide Complexes of the Group 4 Metals: A "Noninnocent" Ligand in Olefin Polymerization. Organometallics 2005, 24, 3279-3289. (c) Nasr, A.; Breuil, P. A.R.; Silva, D. C.; Berthod, M.; Dellus, N.; Jeanneau, E.; Lemaire, M.; OlivierBourbigou, H. New Boron-Containing Molybdenum Imido Alkylidene Complexes for Linear Olefin Homometathesis. Organometallics 2013, 32, 5320-5325.

(12) Coles, M. P. Metal Compounds of Boron-Substituted Alkoxide ('Boroxide') Ligands. Coord. Chem. Rev. 2016, 323, 52-59.

(13) (a) Beck, G.; Hitchcock, P. B.; Lappert, M. F.; Mackinnon, I. A. Lipophilic Lithium Alkoxides or Dialkylboroxides - X-Ray Structures of $\left[\mathrm{Li}(\mu \text {-OR') }]_{2}\right.$ and $\mathrm{Li}\left(\mathrm{OBR}_{2}\right)($ tmeda $)$, $\left[\right.$ tmeda $=\left(\mathrm{Me}_{2} \mathrm{NCH}_{2}\right)_{2} \mathrm{R}=$ $\mathrm{CH}\left(\mathrm{SiMe}_{3}\right)_{2} \mathrm{R}^{\prime}=\mathrm{C}^{t} \mathrm{Bu}_{3}$ or $\left.\mathrm{BR}_{2}\right]$. J. Chem. Soc., Chem. Commun. 1989, 1312-1314. (b) Murphy, D.; Sheehan, J. P.; Spalding, T. R.; Ferguson, G.; Lough, A. J.; Gallagher, J. F. Compounds Containing B$\mathrm{O}$-X Bonds $(\mathrm{X}=\mathrm{Si}, \mathrm{Ge}, \mathrm{Sn}, \mathrm{Pb})$. Part 4. Crystal-Structures of $\mathrm{B}\left(\mathrm{SiPh}_{3}\right)_{3} \mathrm{PhB}\left(\mathrm{OSiPh}_{3}\right)_{2}$ and $\mathrm{PhB}\left(\mathrm{OGePh}_{3}\right)_{2}$. J. Mater. Chem. 1993, 3, 1275-1283. (c) Anulewicz-Ostrowska, R.; Luliński, S.; Serwatowski, J. Synthesis and Characterization of Dialkylmetal Boryloxides [ $(\mu-9-$ BBN-9-O) $\left.\mathrm{MMe}_{2}\right]_{2} \mathrm{M}=\mathrm{Al}$, Ga. Inorg. Chem. 1999, 38, 3796-3800. (d) Anulewicz-Ostrowska, R.; Luliński, S.; Serwatowski, J.; Suwińska, K. Diverse Reactivity of Dialkylaluminum Dimesitylboryloxides [ $(\mu$ $\left.\left.\mathrm{Mes}_{2} \mathrm{BO}\right) \mathrm{AlR}_{2}\right]_{2}$ Synthetic and Structural Study. Inorg. Chem. 2000, 39, 5763-5767. (e) Vidovic, D.; Moore, J. A.; Jones, J. N.; Cowley, A. H. Synthesis and Characterization of a Coordinated Oxoborane: Lewis Acid Stabilization of a Boron-Oxygen Double Bond. J. Am. Chem. Soc. 2005, 127, 4566-4567. (f) Le Coz, E.; Dorcet, V.; Roisnel, T.; Tobisch, S.; Carpentier, J. F.; Sarazin, Y. Low-Coordinate Barium Boryloxides: Synthesis and Dehydrocoupling Catalysis for the Production of Borasiloxanes. Angew. Chem., Int. Ed. 2018, 57, 11747-11751. (g) Someşan, A. A.; Le Coz, E.; Roisnel, T.; Silvestru, C.; Sarazin, Y. Stable Lead(II) Boroxides. Chem. Commun. 2018, 54, 5299-5302.

(14) (a) Weese, K. J.; Bartlett, R. A.; Murray, B. D.; Olmstead, M. M.; Power, P. P. Synthesis and Spectroscopic and Structural Characterization of Derivatives of the Quasi-Alkoxide Ligand [OBMes 2 ]- $\left(\mathrm{Mes}=2,4,6-\mathrm{Me}_{3} \mathrm{C}_{6} \mathrm{H}_{2}\right)$. Inorg. Chem. 1987, 26, 24092413. (b) Chen, H.; Power, P. P.; Shoner, S. C. Synthesis and Spectroscopic and X-Ray Structural Characterization of the First Homoleptic Transition-Metal Boryloxides [Mn $\left(\mathrm{OBTrip}_{2}\right)(\mu$-OB$\left.\left.\mathrm{Trip}_{2}\right)\right]_{2}$ and $\left[\mathrm{Fe}\left(\mathrm{OBMes}_{2}\right)\left(\mu-\mathrm{OBMes}_{2}\right)\right]_{2}$. Inorg. Chem. 1991, 30, 2884-2888. (c) Chisholm, M. H.; Folting, K.; Haubrich, S. T.; Martin, J. D. Triple Bonds between Tungsten Atoms with Ancillary Dimesitylboroalkoxide Ligands. Preparations, Properties and Structures of $\mathrm{W}_{2}\left(\mathrm{NMe}_{2}\right)_{4}\left[\mathrm{OB}(\mathrm{Mes})_{2}\right]_{2}$ and $\mathrm{W}_{2}(\mathrm{OBu})_{4}\left[\mathrm{OB}(\mathrm{Mes})_{2}\right]_{2}$. Inorg. Chim. Acta 1993, 213, 17-24. (d) Gibson, V. C.; Redshaw, C.; Clegg, W.; Elsegood, M. R. J. Synthesis and Structural Characterization of some Novel Metalloboroxides Bearing BoronBound Mesityl and Fluoromesityl Substituents: The Molecular Structure of the First Metallaboroxane Complex. Polyhedron 1997, 16, 2637-2641. (e) Cole, S. C.; Coles, M. P.; Hitchcock, P. B. Transition-Metal Imido-Boroxide Complexes: a Structural and Spectroscopic Investigation of the Influence of Boron. J. Chem. Soc., Dalton Trans. 2002, 4168-4174. (f) Cole, S. C.; Coles, M. P.; Hitchcock, P. B. Neutral and Zwitterionic Group 4 Metal Alkyls with Ancillary Boroxide Ligands. Dalton Trans. 2004, 3428-3430.

(15) Luo, Y. R. Comprehensive Handbook of Chemical Bond Energies; CRC Press: Boca Raton, FL, 2007.
(16) (a) Che, C. M.; Huang, J. S.; Li, Z. Y.; Poon, C. K.; Tong, W. F.; Lai, T. F.; Cheng, M. C.; Wang, C. C.; Wang, Y. Dialkoxyosmium(IV) Porphyrins. Crystal and Molecular-Structures of Diethoxy-, Diphenoxy-, and Bis(2-propanolato) (meso-tetraphenylporphyrinato)osmium(IV). Inorg. Chem. 1992, 31, 5220-5225. (b) Kuhlman, R.; Streib, W. E.; Huffman, J. C.; Caulton, K. G. Site Selectivity in Electrophilic $\left(\mathrm{H}^{+} \mathrm{CH}_{3}{ }^{+}\right)$abstraction on $\mathrm{Os}(\mathrm{H})_{2} \mathrm{X}_{2}\left(\mathrm{P}^{i} \mathrm{Pr}_{3}\right)_{2}$. J. Am. Chem. Soc. 1996, 118, 6934-6945. (c) Cheung, W. M.; Zhang, Q. F.; Williams, I. D.; Leung, W. H. Synthesis, Crystal Structures, and Reactivity of Osmium(II) an -(IV) Complexes Containing a Dithioimidodiphosphinate Ligand. Inorg. Chem. 2007, 46, 57545762. (d) Esteruelas, M. A.; García-Raboso, J.; Oliván, M. Preparation of Half-Sandwich Osmium Complexes by Deprotonation of Aromatic and Pro-aromatic Acids with a Hexahydride Brønsted Base. Organometallics 2011, 30, 3844-3852.

(17) Esteruelas, M. A.; López, A. M.; Mora, M.; Oñate, E. B-H Activation and $\mathrm{H}-\mathrm{H}$ Formation: Two Consecutive Heterolytic Processes on an Osmium-Hydrogensulfide Bond. Chem. Commun. 2013, 49, 7543-7545.

(18) Liu, S. Y.; Légaré, M. A.; Auerhammer, D.; Hofmann, A.; Braunschweig, $\mathrm{H}$. The First Boron-Tellurium Double Bond: Direct Insertion of Heavy Chalcogens into a $\mathrm{Mn}=\mathrm{B}$ Double Bond. Angew. Chem., Int. Ed. 2017, 56, 15760-15763.

(19) Wang, Y.; Hu, H. F.; Zhang, J. Y.; Cui, C. M. Comparison of Anionic and Lewis Acid Stabilized N-Heterocyclic Oxoboranes: Their Facile Synthesis from a Borinic Acid. Angew. Chem., Int. Ed. 2011, 50, 2816-2819.

(20) Esteruelas, M. A.; López, A. M.; Oliván, M. Polyhydrides of Platinum Group Metals: Nonclassical Interactions and $\sigma$-Bond Activation Reactions. Chem. Rev. 2016, 116, 8770-8847.

(21) See, for example: (a) Castillo, A.; Esteruelas, M. A.; Oñate, E.; Ruíz, N. Dihydrido and Trihydrido Diolefin Complexes Stabilized by the $\mathrm{Os}\left(\mathrm{P}^{i} \mathrm{Pr}_{3}\right)_{2}$ Unit: New Examples of Quantum Mechanical Exchange Coupling in Trihydrido Osmium Compounds. J. Am. Chem. Soc. 1997, 119, 9691-9698. (b) Casarrubios, L.; Esteruelas, M. A.; Larramona, C.; Muntaner, J. G.; Oñate, E.; Sierra, M. A. 2Azetidinones as Precursors of Pincer Ligands: Preparation, Structure, and Spectroscopic Properties of CC'N-Osmium Complexes. Inorg. Chem. 2015, 54, 10998-11006.

(22) (a) Pontiggia, A. J.; Chaplin, A. B.; Weller, A. S. Cationic Iridium Complexes of the Xantphos Ligand. Flexible Coordination Modes and the Isolation of the Hydride Insertion Product with an Alkene. J. Organomet. Chem. 2011, 696, 2870-2876. (b) Dallanegra, R.; Chaplin, A. B.; Weller, A. S. Rhodium Cyclopentyl Phosphine Complexes of Wide-Bite-Angle Ligands DPEphos and Xantphos. Organometallics 2012, 31, 2720-2728. (c) Johnson, H. C.; TorryHarris, R.; Ortega, L.; Theron, R.; McIndoe, J. S.; Weller, A. S. Exploring the Mechanism of the Hydroboration of Alkenes by AmineBoranes Catalysed by $[\mathrm{Rh}(\text { Xantphos })]^{+}$. Catal. Sci. Technol. 2014, 4, 3486-3494. (d) Johnson, H. C.; Leitao, E. M.; Whittell, G. R.; Manners, I.; Lloyd-Jones, G. C.; Weller, A. S. Mechanistic Studies of the Dehydrocoupling and Dehydropolymerization of Amine-Boranes Using a $[\mathrm{Rh} \text { (Xantphos) }]^{+}$Catalyst. J. Am. Chem. Soc. 2014, 136, 9078-9093. (e) Johnson, H. C.; Weller, A. S. P-C-Activated Bimetallic Rhodium Xantphos Complexes: Formation and Catalytic Dehydrocoupling of Amine-Boranes. Angew. Chem., Int. Ed. 2015, 54, 10173-10177. (f) Ren, P.; Pike, S. D.; Pernik, I.; Weller, A. S.; Willis, M. C. Rh-POP Pincer Xantphos Complexes for C-S and C-H Activation. Implications for Carbothiolation Catalysis. Organometallics 2015, 34, 711-723. (g) Adams, G. M.; Weller, A. S. POP-Type Ligands: Variable Coordination and Hemilabile Behaviour. Coord. Chem. Rev. 2018, 355, 150-172. (h) Adams, G. M.; Colebatch, A. L.; Skornia, J. T.; McKay, A. I.; Johnson, H. C.; Lloyd-Jones, G. C.; Macgregor, S. A.; Beattie, N. A.; Weller, A. S. Dehydropolymerization of $\mathrm{H}_{3} \mathrm{~B} \cdot \mathrm{NMeH}_{2}$ To Form Polyaminoboranes Using [Rh(Xantphosalkyl)] Catalysts. J. Am. Chem. Soc. 2018, 140, 1481-1495.

(23) (a) Stalick, J. K.; Ibers, J. A. Crystal and Molecular Structure of Tricarbonylbis(triphenylphosphine) osmium $(0), \mathrm{Os}(\mathrm{CO})_{3}(\mathrm{P}-$ $\left.\left(\mathrm{C}_{6} \mathrm{H}_{5}\right)_{3}\right)_{2}$. Inorg. Chem. 1969, 8, 419-423. (b) Fiedler, T.; 
Bhuvanesh, N.; Hampel, F.; Reibenspies, J. H.; Gladysz, J. A.

Gyroscope Like Molecules Consisting of Trigonal or Square Planar Osmium Rotators within Three-Spoked Dibridgehead Diphosphine Stators: Syntheses, Substitution Reactions, Structures, and Dynamic Properties. Dalton Trans. 2016, 45, 7131-7147. (c) Bissert, R.; Braunschweig, H.; Dewhurst, R. D.; Schneider, C. Metal-Only Lewis

Pairs Based on Zerovalent Osmium. Organometallics 2016, 35, 2567-

2573. 